\title{
Virtual models of care for people with palliative care needs living in their own home: a systematic meta-review and narrative synthesis
}

\author{
Abstract \\ Background: Access to palliative care in the community enables people to live in their \\ preferred place of care, which is often home. Community palliative care services struggle to \\ provide timely 24-hour services to patients and family. This has resulted in calls for \\ 'accessible and flexible' models of care that are 'responsive' to peoples' changing palliative \\ care needs. Digital health technologies provide opportunities to meet these requirements \\ 24-hours a day.
}

Aim: To identify digital health technologies that have been evaluated for supporting timely assessment and management of people living at home with palliative care needs and/or their carer(s), and the evidence-base for each.

Design: A systematic review of systematic reviews ('meta-review'). Systematic reviews evaluating evidence for virtual models of palliative or end-of-life care using one or more digital health technologies were included. Systematic reviews were evaluated using the Risk of Bias Tool for Systematic Reviews. A narrative approach was used to synthesise results. Data sources: Medline, Embase, Web of Science, CINAHL and Cochrane Database of systematic reviews were searched for English-language reviews published between 20152020.

Results: The search yielded 2,266 articles, of which 12 systematic reviews met criteria. Sixteen reviews were included in total, after four reviews were found via handsearching. Other than scheduled telehealth, video-conferencing, or after-hours telephone support, little evidence was found for digital health technologies used to deliver virtual models of palliative care.

Conclusions: There are opportunities to test new models of virtual care, beyond telehealth and/or video conferencing, such as 24-hour command centres, and rapid response teams.

Systematic Review Registration Number: Prospero CRD42020200266

Key statements: 


\section{What is already known about the topic?}

- Many community palliative care services struggle to provide a 24-hour service, and respond appropriately to the needs of patients and family in a timely way Recent advancements in digital health technologies provide opportunities to meet these requirements 24 hours a day.

\section{What this paper adds}

- There is limited evidence existing on the use of digital health technology, beyond scheduled video-conferences or telehealth to deliver integrated virtual models of community palliative care.

- Further evidence is required to determine the use of digital health technology applications to provide a rapid virtual response, proactive care planning, or the use of analytics to predict deterioration in patients with palliative care needs in the community.

\section{Implications for practice, theory or policy}

- Understanding how to harness and adapt emerging digital health technologies such as command centres, rapid response teams and decision analytics modelling to improve care for terminally ill patients and their carers is critically important and ought to be the focus of future well-designed effectiveness trials.

Keywords: Virtual care; palliative care, telehealth; eHealth; rapid response; remote patient monitoring; digital health technology; community 


\section{Introduction}

COVID-19 has accelerated the adoption globally of various digital health technologies to provide care virtually. Virtual care is defined as "...any interaction between patients and/or members of their circle of care, occurring remotely, using any forms of communication or information technologies, with the aim of facilitating or maximising the quality and effectiveness of patient care" (p. 2). ${ }^{1}$ The integration of information and communication technologies and networks for the management of healthcare, (i.e. telehealth, mobile health ('mHealth'), electronic health ('eHealth')) $)^{2-4}$ facilitates the delivery of virtual care to patients and families in different locations. ${ }^{5}$ When fully optimized, digital health technology can facilitate the delivery of care that is continuously connected, coordinated across settings, delivered virtually but augmented with and integrated into existing face to face models of care. ${ }^{6}$ Virtual care has been demonstrated to: improve clinical outcomes in many specialties, enhance patient experiences, expand patient and clinician access, reallocate costs and improve efficiencies and enhance care coordination. ${ }^{6}$

Timely access to optimal palliative care in the community is critical to enabling people to live as well as possible, optimizing time in their preferred place of care, which is most often home. While staying at home is desired by most, evidence suggests that home-based care may not perform as well as inpatient care in some domains, especially in terms of symptom burden. ${ }^{7}$ Inadequate symptom control and unanticipated clinical events or deterioration contribute to unnecessary emergency department (ED) visits for people with palliative care needs, especially after-hours. ${ }^{8,9}$ Access to 24 -hour professional support and advice is an essential element of all community palliative care services. ${ }^{10}$ These 24 -hour telephone support services are probably the earliest form of virtual palliative care, ${ }^{11}$ and evidence suggests they are called upon to assess unanticipated issues that have arisen for the community palliative care patient, support the previously made care plans, and/or carers who require support to cope with their role. Despite the importance of 24-hour access, many community palliative care services struggle to sustain this level of coverage. ${ }^{12}$ Calls for new models of palliative care to be more 'accessible', 'flexible' and 'responsive' to peoples' changing palliative care needs and preferences have been made. However, little is known about how these new models of virtual palliative care ought to be configured, resourced ${ }^{13}$ 
and what are the barriers and facilitators to adopting the various digital health technologies to deliver on this promise. ${ }^{13}$

\section{Aim}

To identify the digital health technologies that have been evaluated for supporting timely assessment and management of people living at home with palliative care needs and/or their carer(s), and the evidence-base for each.

\section{Methods}

\section{Design}

A meta-review (a systematic review of systematic reviews) was undertaken in order to bring together a comprehensive summary of the evidence where there is more than one review on an important topic. ${ }^{14}$ Meta-reviews allow for reviews of variable quality, scope and strength review's to be compared and discussed. ${ }^{14}$ The rationale for conducting a metareview was due to the plethora of recent systematic reviews on digital health applications in palliative care. While digital applications are rapidly evolving, a preliminary search of the literature suggested there was little evidence of initiatives beyond tele- and videoconferencing, and remote patient monitoring. Guidance from the Joanna Briggs Institute informed the design, conduct and reporting of this meta-review. ${ }^{15}$ The Preferred Reporting Items for Systematic Reviews and Meta-analyses (PRISMA) Statement was used to guide reporting for this meta-review. ${ }^{16}$

In this meta-review, systematic reviews are referred to as 'reviews', while studies contained within these 'reviews' are referred to as 'studies' (p.15). ${ }^{17}$ This meta-review sought to answer the following research questions:

1) What digital health technologies have been used to provide timely and responsive clinical assessment and facilitate remote clinical decision making for palliative patients living at home who require an (unscheduled) clinical review?

2) What was the impact of these virtual models of palliative care on clinical outcomes?

3) What are the barriers and facilitators to delivering an integrated virtual model of care to people living at home with palliative care needs? 


\section{Protocol and registration}

${ }^{15}$ The review protocol has been registered in an international prospective register of systematic reviews (PROSPERO CRD42020200266) (http://www.crd.york.ac.uk/prospero/).

\section{Eligibility criteria}

Systematic reviews (with or without meta-analysis) of original, evaluative studies, including quantitative, qualitative or mixed methods that adhered to the Cochrane Collaboration and the PRISMA statement ${ }^{16,18}$ were eligible for inclusion if they were: published in English in a peer-reviewed journal; between 2015-2020; focused on digital health technology interventions that allowed people with advanced progressive illness living in the community, as defined by the Supportive and Palliative Care Indicators Tool (SPICT) ${ }^{19}$ and/or their family carers to receive virtual palliative care. Interventions were included if they described a virtual model of palliative care which utilises digital health technology to facilitate: a responsive assessment; decision-making; triage and/or the development of a short-term action or care plan, allowing for clinical information sharing and/or communication between clinician(s) and the person living with palliative care needs at home and/or their carer in response to a patient's clinical need.

Systematic reviews that incorporated only opinions as their primary source of evidence, were excluded, as were systematic reviews on virtual models of care focused on chronic disease self-management (i.e. education or behavioural interventions targeted at secondary disease management) and lifestyle modification such as 'aging in place' interventions, 'health smart homes', assisted living technologies, home care 're-ablement' interventions (i.e. after a stroke), or remote communication solely between clinicians without patient and/or carer inclusion.

\section{Information sources}

Databases searched included Medline, Embase, CINAHL, Web of Science and the Cochrane Database of systematic reviews.

\section{Data search}

A comprehensive search strategy was developed using Medical Subject Headings and keywords relating to end-of-life care, palliative care, terminal care, and hospice combined 
with terms relating to digital health technologies that supported virtual models of care including 'telehealth,' 'video-conferencing,' 'telemedicine,' 'telecommunication,' 'eHealth', 'mHealth,' 'virtual care,' 'command centre,' 'concierge,' 'remote patient monitoring' or 'RPM,' 'out-of-hours' or 'after-hours care,' 'unscheduled,' 'rapid response,' 'remote consultation,' 'e-triage' and 'information and communication technology'. The Scottish Intercollegiate Guidelines Network (SIGN) search filter was used to specify the search process with a predefined set of keywords to locate systematic reviews and meta-analyses. Reference lists of all included reviews and articles were also manually searched for further relevant systematic reviews and meta-analyses. Secondary searching of the reference lists of retrieved papers and of the internet via Google scholar search engine was undertaken to identify any additional reviews that met the inclusion criteria.

\section{Data inclusion/exclusion}

\section{Study selection}

Returned articles from database searches were imported into Endnote Version 9, and duplicates removed automatically and double checked manually. Titles and abstracts were then reviewed and screened against criteria by one team member (DD), with 147 full text articles assessed independently by two team members (DD and JLP). Disagreements regarding the eligibility of studies were resolved via discussion and consensus with both team members, and an additional investigator, when necessary.

\section{Data extraction process and items}

A standardised form for extracting data and relevant information from included reviews was developed (DD and JLP) following Aromataris et al., guidance. ${ }^{15}$ Outcomes of interest were: improved clinical health outcomes for people with palliative care needs and/or their carers at home, such as: enhanced quality of life; a reduction in unnecessary hospitalisation or emergency department admissions; and lower hospitalisation costs. The feasibility and costeffectiveness of interventions were also of interest. Data from eligible studies were extracted by one reviewer (DD) and double checked (JLP). 


\section{Risk of bias in individual studies}

Included reviews were appraised for the extent to which they had followed the 27 PRISMA Statement checklist. ${ }^{16}$ The JBI three phase Risk of Bias Tool for Systematic Reviews (ROBIS) was then applied. ${ }^{20}$ Any disagreement regarding the evaluation of studies was resolved through discussion and consensus involving both reviewers and a third author, when necessary.

\section{Synthesis of results}

The initial search (up to 29 October, 2020) yielded 2,266 citations. After removal of 763 duplicate references and screening titles and abstracts, 147 full-text reviews were retrieved for further assessment. After further assessment, 12 reviews were met inclusion criteria. A further four reviews were found via hand searching. A total of 16 reviews were included for synthesis (Refer Figure 1).

A narrative approach using the UK's Economic and Social Research Council ${ }^{21}$ methods was used to synthesise the systematic review results.

(Insert Figure 1 here)

\section{Results}

The 16 included reviews synthesised evidence from 159 papers reporting on 150 relevant studies published between 1997 and 2019. Three quarters of studies ( $n=78,52 \%$ ) were reported in only one of the 16 reviews, while a very small proportion $(n=4,3 \%)$ of studies ${ }^{22-}$ 25 were reported in five reviews. The reviews captured studies from a diverse range of countries, age groups, diseases, digital health technology and virtual care strategies, and outcome measures (Refer Table 1 for characteristics of included reviews).

(Insert Table 1 here)

Most reviewers ( $n=10)$ concluded there was insufficient evidence to support the use of integrating digital health technology into existing models of palliative care. ${ }^{26-35}$ The paucity of intervention details was highlighted as a major limitation in many reviews, making it difficult to determine which elements of many virtual care interventions were effective. ${ }^{27,29}$, 32,34 
The overall level of evidence was low. Less than a tenth $(n=11,7 \%)$ of studies included in the reviews were randomised controlled trials (RCTs) (Level 1b evidence) involving: scheduled telephone intervention $(n=5)^{36-44}$ or scheduled video consultations $(n=2), 23,45$ or RPM of palliative care symptoms $(n=2) .46,47$

The remainder of studies generated a much lower level of evidence ranging from: Level 4 (case studies) evidence $(n=42,28 \%)$; qualitative studies $(n=37,25 \%)$ (i.e. mostly in-depth interviews with clinicians, patients and carers exploring user satisfaction of different virtual care modalities) or expert opinion (16,11\%) (Level 5 evidence) (Refer Table 2 for summary of included reviews).

(Insert Table 2 here)

\section{Risk of bias within reviews}

The majority $(n=10)$ of reviews had a low for risk of bias score, ${ }^{26,28-30,33,35,48-51}$ while the highest risk of bias was noted in a recent review. ${ }^{52}$ The risk of bias in the remaining reviews

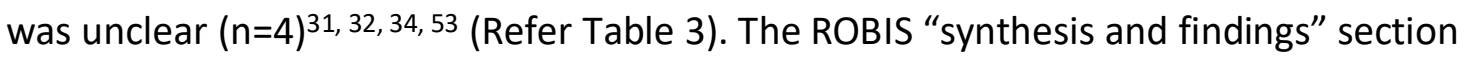
generated the highest level of bias related to the heterogeneity in the included studies, and no observed meta-analyses or sensitive analyses to develop robust findings.

(Insert Table 3 here)

\section{Synthesis of results}

\section{Video consultations}

The overall consensus in the reviews was that scheduled video consultations are an effective, accessible and a cost-effective way to deliver healthcare remotely but are not better than face-to-face consultations. However, it was noted that if scheduled videoconferencing is to be augmented with usual palliative care, then services needed to ensure that the software is simple, effective, reliable and safe, with the highest level of security for confidentiality. 52

Video consultations, using a variety of applications were predominately adopted by high-

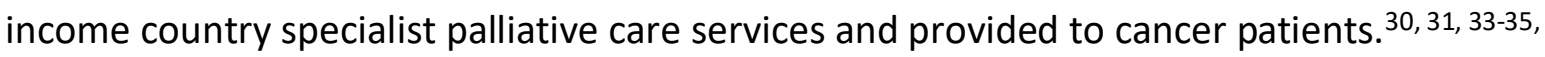
48-53 Scheduled follow-up video consultations, involving the patient, family and/or other clinicians were often employed after the initial face-to-face specialist palliative care 
consultation ${ }^{49,52}$ and focused on providing ongoing clinical support or symptom management and/or psychotherapy. ${ }^{35,48}$

Six reviews that included two Phase III RCTs ${ }^{23,45}$ (Level 1b evidence) found scheduled video consultations to be as effective as conventional face to face palliative care consultations. ${ }^{33-}$ $35,49,51,52$ While the Hebert et al. ${ }^{23}$ RCT found no additional improvements with the use of video capabilities, the Demiris et al. ${ }^{45}$ RCT showed a significant improvement in carers' quality of life and reduction in their anxiety for those using scheduled video consultations.

\section{Telephone consultations}

Mixed evidence emerged from the 9 reviews reporting on the effectiveness of scheduled telephone consultations. ${ }^{26,31,33-35,48,51,53}$ Telephone consultations were used for counselling, ${ }^{34,51}$ delivery of nursing support, ${ }^{31,34,50}$ education, ${ }^{50}$ and multidisciplinary team communication. ${ }^{50}$

Seven Phase III RCTs (Level 1b evidence) ${ }^{36-42,44,54,55}$ tested scheduled telephone consultations and generated mixed results. All of these interventions augmented scheduled telephone support with either: psycho-educational support, ${ }^{36-39}$ automated symptom monitoring; 54 or nursing support. ${ }^{42,} 44$ The INCPAD (Indiana Cancer Pain and Depression) trial ${ }^{43,54,56}$ reported in Allsop et al. ${ }^{29}$ review, augmented scheduled telephone support with automated symptom management to significantly improve advanced cancer pain $(P<.001)$ and depression outcomes $(\mathrm{P}<.001)$. The ENABLE trial, reported in Pinto et al. review ${ }^{53}$ similarly improved quality of life $(P=.02)$ and depression $(P=.02) .{ }^{36}$ Two end-stage renal failure Phase III RCTs found that a nurse-led scheduled telephone follow-up post-discharge: 1) improved peritoneal dialysis patients well-being, pain and fatigue ${ }^{44}$ (both reported in the Lunney et al. ${ }^{31}$ review); and 2) significantly improved depression $(P=.05)$, anxiety $(P=.01)$ and stress scores $(\mathrm{P}=.001)$ in community haemodialysis patients. ${ }^{41}$ In the Phase III RCT ${ }^{42}$ (Level $1 \mathrm{~b}$ evidence) telephone monitoring reduced patients anxiety $(P<.0001)$, depression $(P<.0004)$, and overall distress $(P<.0001)$ and a similar trial reported significantly fewer outpatient clinic visits at 12 weeks. ${ }^{44}$

However, a Phase III RCT (Level 1b evidence) $)^{55}$ included in the Ostherr et al. ${ }^{50}$ review found no difference in the care outcomes of community palliative care patients who received scheduled telephone access to multidisciplinary specialist palliative care team advice and 
support compared with limited telephone advice, with both groups reporting significant improvements in: symptoms $(P<.001$ vs. $<.001)$, health-related quality of life $(P<.001$ vs. $0.044)$, mood ( $P<.001$ vs. 0.13 ) and emotional problems ( $P<.001$ vs. 0.008$)$, suggesting either models of telephone support can result in improvements in health-related outcomes. ${ }^{55}$ Conversely, Phase III ImPaCT RCT found that weekly palliative care telephone consultations $(\mathrm{N}=74)$ led to worse anxiety scores $(P=.04)$ and no difference in depression scores $(P=.73)$ compared to usual care among 'home-dwelling' patients with advanced cancer (Level $1 \mathrm{~b}$ evidence). ${ }^{40}$ Excess attention on symptoms and (potential) suffering, the supply-driven care model for telephone consultations in the trial, and the already high level of specialist palliative care provided to the control group in the study may have contributed to these results. ${ }^{40}$

\section{Remote patient monitoring (RPM)}

Eight reviews reported on RPM as part of a virtual model of palliative care. ${ }^{26,29-31,33,35,50,53}$ These RPM interventions included the monitoring of biometric data (i.e. heart rate, blood pressure, respiration rate) or symptoms such as pain, either actively by nurses or through generated alerts to clinicians when patient scores reported outside of a predetermined acceptable threshold, ${ }^{35,50}$ both within hours and after-hours. Patients manually inputted data on symptoms specific to their illness using their telephone landline, television or computer hardware and software. Alerts triggered clinicians remotely to contact the patient or to visit them at home.

Two phase III, RCTs testing the effectiveness of RPM (Level $1 \mathrm{~b}$ evidence) ${ }^{46,47}$ reported no difference in outcomes. The TeleCRAFT trial involving patients with chronic obstructive pulmonary disease found no difference in median number of days spent at home $(P=.189)$ or quality of life $(P=.270) .{ }^{46}$ This RPM intervention actually increased hospital admissions $(P=.026)$ and home visits overall, ${ }^{46}$ reflecting the need for a clinical review based on abnormal parameters and potentially an inability to review the patient virtually. Conversely, the other RPM RCT which sent alerts directly to the patient's surgeon reduced postoperative symptoms in patients with advanced lung cancer or lung metastases (75\% Stages III and IV lung cancer) $(\mathrm{P}=.02) .47$ 


\section{Mobile applications}

Eight reviews described the use of smartphone and mobile applications ('apps') to allow for communication and information sharing between patients and/or carers and clinicians. ${ }^{28,32-}$ 35, 48, 50, 53 Two systematic reviews ${ }^{28,53}$ provided comprehensive lists of available apps relevant to palliative populations which: provide information on palliative care medication; enhancing communication; provide systems to monitor and assess symptoms; and synthesise patient information and end-of-life care wishes. Limited information was provided as to whether these mobile applications allowed for after-hours contact with clinicians. However, no well-designed studies have tested the effectiveness of these apps or their impact on delivering virtual models of care.

\section{Telephone advice and support lines}

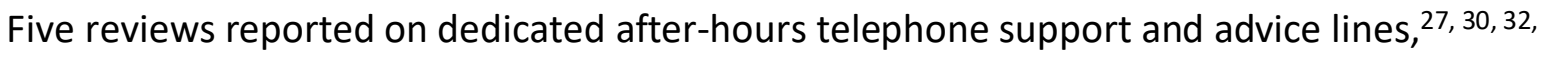
33,50 and has been reported as the most common type of digital health technology used to provide a virtual palliative care model. ${ }^{57}$ However, none of the studies reported in included reviews generated robust (level $1 \mathrm{~b}$ ) evidence. Telephone advice and support lines required adequate staffing and infrastructure support in order to be sustained. ${ }^{57}$ Despite palliative care telephone advice lines being widely adopted, a recent review ${ }^{27}$ was unable to determine the effectiveness and cost-effectiveness of after-hours palliative care telephone support and advice lines, due to a paucity of suitably designed studies. ${ }^{27}$

\section{Barriers and facilitators to delivering a virtual model of community palliative care}

Five reviews described a range of barriers and facilitators that impact on the delivery of virtual models of community palliative care ${ }^{34,35,48,49,52,53}$ (Refer Table 4).

Barriers: Four reviews reported clinicians concerns that video consultations and RPM devices are inappropriate for this population due to illness burden and potential for rapid deterioration. ${ }^{30,34,35,52}$ Several reviews highlighted clinician preference for face-to-face interactions over virtual encounters ${ }^{48,49}$ because it allows for better engagement, observation and examination of the patients, ${ }^{53}$ and an opportunity to discuss sensitive topics and to comfort distressed patients. ${ }^{48,52}$ Technical issues were considered major barriers to providing virtual care, especially limited broadband or internet access ${ }^{30,53}$ and slow internet speed affecting the quality of the video and audio resolution. ${ }^{48,49,52}$ 
Facilitators: Four reviews also highlighted clinicians positive perceptions of video enabled consultations due its ability to enable digital connectedness, $35,48,49,52$ and a way to observe body language and nonverbal cues, and to understand the patient's health status and make appropriate changes to their management plan. Building patients and families digital health capabilities was considered a key facilitator to the success and viability of virtual models of care, especially for older people and those less familiar with technology. ${ }^{48,49,52,53}$ Tailoring the use of technology to patients and carer preferences and capabilities was also noted as being important. ${ }^{48,49,51}$ Building clinicians' video consultation capabilities is also critical to improving the quality of virtual palliative care service delivery. ${ }^{49,}{ }^{52}$ Several reviews highlighted the need for improved infrastructure and access to external supports to optimise the integration of available digital health teachnology into existing models of care. ${ }^{30,48,49,52}$

\section{(Insert Table 4 here)}

\section{Impact on health service utilisation}

There was mixed evidence of the impact of virtual palliative care on health service utilisation. Three reviews reported on hospital and emergency department visits, ${ }^{30,31,34}$ and four reviews reported on cost-effectiveness. ${ }^{27,33,34,52}$ As most of this data was generated from Phase II studies, it is difficult to draw any firm conclusions.

Five studies in the Lunney et al. ${ }^{31}$ reported on the impact of virtual care strategies as an adjunct to usual palliative care on health services utilization for patients with ESRD, with four studies finding positive results, ${ }^{44,58-60}$ with only one a Phase III trial design. ${ }^{44}$ Li et al. ${ }^{44}$ reported significantly fewer clinic visits with telehealth at 12 weeks following implementation. Two Phase II trials reported encouraging findings which could not be confirmed, while the other detected no difference. ${ }^{58,60,61} \mathrm{~A}$ third review ${ }^{30}$ which included a very different group of studies, reported insufficient evidence to appreciate any benefit of telehealth on emergency department visits.

Three reviews reported on cost-effectiveness of virtual care strategies for palliative care, ${ }^{27}$, 34,52 with two reporting positive outcomes. ${ }^{34,52}$ Sutherland et al. review ${ }^{52}$ included two Phase III trials showing a cost reduction by providing patients with technology to access video consultations compared with outpatient appointments or inpatient admission. ${ }^{23,45}$ 
Head et al. review ${ }^{34}$ included two studies which showed virtual care can significantly drop hospital care costs, 62,63 however these were from Phase II trial results.

\section{Discussion}

Overall, there is insufficient evidence describing the impact of integrating virtual care strategies into existing community palliative care models. Due to the low quality of evidence, it was difficult to evaluate the individual effectiveness of the four main digital health technology strategies (i.e. information and communication technology, telehealth, mHealth, and eHealth) employed to deliver a virtual model of care to community palliative care patients.

Despite the proliferation of reviews, there is insufficient evidence available to identify the key elements of an optimal integrated virtual community palliative care model. Few of the reviews detailed virtual care intervention that provided responsive clinical assessment or facilitated remote care to this population, including an unscheduled and rapid clinical review. Compounding this problem, is the lack of population level prevalence data to guide planners as to the actual need for unscheduled reviews and the triggers and timing of this need in the context of people with palliative care needs living at home.

After-hours, unscheduled, e-triage or rapid response elements were minimally if at all described in any of the virtual care interventions reported on in this meta-review. While 24hour telephone support lines are the oldest and most widely adopted virtual model of palliative care, there is little evidence demonstrating their effectiveness. ${ }^{27}$ Scheduled video or telephone consultations were the most commonly used digital health technology to provide virtual care, which are neither new nor novel. Of note, none of the reviews reported on or mentioned the need to develop and test more integrated virtual models of community palliative care or the potential role of providing: real-time assessment, triage and/or review via 24-hour command centres; or concierge services to assist palliative care patients and their carers navigate their care needs in a timely manner.

The COVID-19 pandemic has accelerated the global uptake of digital health with healthcare organisations rapidly adopting virtual care solutions. A recent systematic review looking at the uptake of digital health solutions to mitigate the impact of COVID-19 on people in health systems identified numerous suggestions on the use of artificial intelligence powered tools 
for diagnosis and screening for the virus. ${ }^{64}$ Similar to this meta-reviews' findings, the use of telehealth tools like video-conferencing and apps were proposed. Th historical moment associated with this pandemic may encourage decisive large-scale adoption in the healthcare system, which have been particularly resistant in the past, and hopefully a greater integration into homebased palliative care programs.

Future integrated models of virtual palliative care need to apply the lessons learned through the pandemic as well as from previous after-hours initiatives. ${ }^{65,66}$ It will be critical to ensure that that communication between community patients and members of their healthcare team is: flexible, responsive and tailored to regional circumstance; makes efficient and effective use of the broader health workforce; and uses data to drive improvements and inform policy. ${ }^{66}$

There was also no consideration or explanation in any of the included reviews of the importance of providing integrated virtual palliative care across diverse: services (i.e. public and private); settings (i.e. primary, acute or aged care); and/or team members (i.e. general practitioner, community nurses, specialist providers). There is a need for virtual palliative care to move towards integration of scheduled and after-hours telehealth services in order to provide timely and responsive care across a large region, with quality care provided within hours and after-hours guided principally on patient need. Healthcare organisations adopting an enterprise approach that maximises resources, creates more efficient operations, consolidates the limited workforce, delivering care to scale and breaking down silos of care. ${ }^{67}$

Moving to an integrated virtual palliative care model also requires consideration of a number of factors. Establishing a virtual model of palliative care is in essence not just the introduction of new technology, but rather the creation of a new service. ${ }^{68}$ Drawing on their digital health technology and palliative care expertise, Calton et al. ${ }^{69}$ highlighted that the most successful virtual palliative care models are those that: 1) complete a service needs assessment; 2) have a billing model; and 3) build clinician's capabilities to optimise the provision of virtual care and to recognise when in-person care is required. ${ }^{69}$ Applying the simple heuristic 'Tool, Team and Routine' framework will help palliative care services to identify the key questions, stakeholders and issues requiring attention to enable an effective virtual model of care to be effectively established. ${ }^{68}$ The type of issues that will need to be 
considered in order to operationalize a virtual model of palliative care, include: the development of standardised agreed comprehensive assessments, proactive care planning by day-time team and standardised interdisciplinary team handover and communication processes. Further development of the virtual palliative care evidence-base is required to understand its impact on patient and clinician experiences, patient outcomes such as symptom management and well-being, health service utilisation, and costs; and quality and safely. ${ }^{69}$

A Phase II prospective cohort study has demonstrated the feasibility and acceptability of an integrated multicomponent digital health intervention for community-based patients $(n=43)$ seen by a specialist palliative care service. ${ }^{70}$ Integration of video and self-reported outcome measures fed back to specialists helped to identify patients in need of a timely review of care ${ }^{70}$ with clinicians reporting video consultations as similar or better/much better than phone calls or face-to-face visits. ${ }^{70}$ However, delivering this model of virtual care required timely technical support, increase in service staff to manage the volume of alerts generated and address the impacts of these service changes on team functioning.

There is conflicting evidence on the effects of virtual models of palliative care on the use of hospital department and emergency department visits. ${ }^{30,31,34}$ While all of the Phase III virtual care trials demonstrated reduced health service utilization, ${ }^{23,44,45}$ none considered the impact on safety and quality of the care provided. Determining what can be realistically managed virtually and which clinical situations demand a face-to-face review is an important next step. While any virtual intervention that enables community palliative patients to spend even another day 'safely' at home is likely to reduce healthcare costs, there is a need to ensure that it doesn't increase carer distress, burden or impact adversely on household finances. Future research needs to evaluate the impact of new models of virtual care in healthcare service utilisation and costs.

Numerous barriers and facilitators at the system, health provider and patient level have been identified in this meta-review, as summarised below.

Systems level: Limited broadband or internet access, and slow internet speed are major barriers to providing virtual care. The 2018 cross sectional American Survey, ${ }^{71}$ found that $26.3 \%$ of Medicare beneficiaries, mainly older people, those with low socio-economic status and those from minority ethnic communities, lacked digital access at home, which limited 
their opportunity to receive virtual healthcare (i.e. video consultations with clinicians). ${ }^{71}$ Similarly, it is estimated that 2.5 million Australians are not online which impacts on their ability to benefit from innovative models of virtual care. ${ }^{72} \mathrm{~A}$ lack of digital inclusion has the potential of widening disparities in care and will adversely impact the delivery of new accessible and affordable virtual models of palliative care that are available to all.

Clinicians: Several reviews reported clinicians concerns that virtual care is not always appropriate for palliative populations due to their age, symptom burden and potential for rapid deterioration. ${ }^{30,34,35,52}$ While several reviews documented health professional preference for face-to-face consultations with patients, the global COVID-19 pandemic has triggered the expansion of digital health technology to provide virtual care, and a shift in health professional's attitude and overall uptake. ${ }^{64}$ Determining what palliative care needs can be managed virtually and what needs require in-person assessment, at home or in hospital is essential to developing a sustainable, safe, high quality virtual model of palliative care.

Patients and carers: Palliative care patients in the community require close follow-up in order to identify changing palliative care needs. ${ }^{73} \mathrm{~A}$ virtual model of palliative care addresses these needs by optimising existing digital health technology to respond rapidly to the alerts triggered by RPM, via a bi-directional remote communication system that allows for assessment, planning and triage at any time of the day or night. Considering how to support older and digitally inexperienced patients to build their level of digital health technology confidence and preparedness to engage with virtual care is an important consideration of any future models of virtual palliative care. This is especially important with $72 \%$ of adult Americans aged over 85 years living at home identified as unprepared to participate in video and telephone consultations, ${ }^{74}$ due to inexperience with technology, lack of social support to instruct them on using this technology, and lack of confidence about interacting virtually. Hearing, communication difficulties or dementia limited a fifth $(20 \%)$ of these older adults from participating in scheduled telephone consultations. ${ }^{74}$ Addressing these barriers along with building patients and families' digital health capabilities is a key facilitator to enabling the delivery of any virtual model of care. 


\section{Limitations and strengths}

This meta-review has a number of limitations and strengths. Most included reviews defined 'virtual care' very broadly and did not attempt to delineate the effectiveness of the various digital health technologyused to provide timely care to people with palliative care needs living at home. The inconsistency and heterogeneity in the definition and terminology of telehealth in the literature has been long noted as a major challenge, ${ }^{75}$ and may have led to relevant reviews being excluded. The studies included in the various reviews were heterogeneous in terms of the digital health technology used to provide virtual care, intervention duration, populations studied and outcomes assessed. This heterogeneity limited the ability of any of the reviews to undertake a meta-analysis. While publication bias is a risk because the search did not extend to the grey literature, this is balanced by the group consensus methods which have mitigated against this risk. Conducting a meta-review may have precluded more recent virtual care interventions (i.e. 24-hour concierge and teleporting) from being captured. However, this limitation is off-set by this being the first metareview of its kind focusing on understanding the use of digital health technology to support the delivery of an integrated model of virtual community palliative care. The limited overlap of original studies between included reviews supports the rationale for adopting the metareview design. While adherence with the internationally recognised protocol for the conduct and reporting of systematic reviews, the PRISMA Statement ${ }^{16}$ strengthens the validity of the results.

\section{Conclusions}

There is limited evidence that existing digital health technology, beyond scheduled videoconferences or telehealth are being fully optimised to deliver integrated virtual models of community palliative care. To date, there has been little focus on using digital health technology applications to provide a rapid virtual response or to provide new services. There is also little evidence of proactive care planning, or the use of analytics to predict deterioration in patients. Despite these gaps, there is great potential to develop and test integrated virtual care interventions that will help to revolutionise the delivery and organisation of healthcare for people with palliative care needs who wish to spend as many days as possible at home. Understanding how to harness and adapt new and emerging digital health technology to improve care for terminally ill patients and their carers is 
critically important and ought to be the focus of future well-designed effectiveness trials and decision analytic modelling.

\section{Authorship}

All authors contributed to the concept and design of the study. DD and JLP contributed to the data acquisition, analysis and interpretation of the data. All authors contributed to drafting the article, and critically revising. All authors approved the version to be published.

\section{Funding}

This project was awarded funding by the Sydney Partnership for Health, Education, Research and Enterprise (SPHERE) - Palliative Care Clinical Academic Group (PC-CAG) under the Seed Grant Scheme, 2019.

\section{Declaration of conflicts of Interest}

The authors declare that there is no conflict of interest.

\section{Abbreviations}

CINAHL: Cumulative Index to Nursing and Allied Health Literature

PC-CAG: Palliative Care Clinical Academic Group

PRISMA: Preferred Reporting Items for Systematic Reviews and Meta-analyses

$\mathrm{RCT}$ : randomised controlled trial

ROBIS: Risk of Bias Tool for Systematic Reviews

RPM: remote patient monitoring

SIGN: Scottish Intercollegiate Guidelines Network

SPHERE: Sydney Partnership for Health, Education, Research and Enterprise

SPICT: Supportive and Palliative Care Indicators Tool

\section{References}

1. Shaw J, Jamieson T, Agarwal P, et al. Virtual care policy recommendations for patient-centred primary care: findings of a consensus policy dialogue using a nominal group technique. Journal of Telemedicine and Telecare 2018; 24: 608-615.

2. Ahmadvand A, Kavanagh D, Clark M, et al. Trends and Visibility of "Digital Health" as a Keyword in Articles by JMIR Publications in the New Millennium: 
Bibliographic-Bibliometric Analysis. Journal of Medical Internet Research 2019; 21: e10477. DOI: 10.2196/10477.

3. Pagliari C, Sloan D, Gregor P, et al. What Is eHealth (4): A Scoping Exercise to Map the Field. Journal of Medical Internet Research 2005; 7: e9. Review \%J J Med Internet Res 31.3.2005. DOI: 10.2196/jmir.7.1.e9.

4. US Food and Drug Administration. Digital health, (2020, accessed 27 August 2020).

5. World Health Organization. WHO guideline: recommendations on digital interventions for health system strengthening. 2019. Switzerland.

6. Deloitte. Virtual Care by Deloitte. February 2019 2019. Sydney, Australia.

7. Clark K, Connolly A, Clapham S, et al. Physical symptoms at the time of dying was diagnosed: a consecutive cohort study to describe the prevalence and intensity of problems experienced by imminently dying palliative care patients by diagnosis and place of care. Journal of Palliative Medicine 2016; 19: 1288-1295.

8. Henson L, Gao W, Higginson I, et al. Emergency department attendance by patients with cancer in the last month of life: a systematic review and meta-analysis. The Lancet 2015; 385: S41. DOI: https://doi.org/10.1016/S0140-6736(15)60356-7. 9. Swerissen H, Duckett S and Farmer J. Dying well. Grattan Institute Melbourne, 2014.

10. National Institute for Health Clinical Excellence. Improving supportive and palliative care for adults with cancer: research evidence. 2004. London: NICE.

11. Johnston B. UK telehealth initiatives in palliative care: a review. International Journal of Palliative Nursing 2011; 17: 301-308.

12. Palliative Care Australia. Investing to save: the economics of increased investment in palliative care in Australia. 2019. Canberra: KPMG.

13. Australian Government. National Palliative Care Strategy 2018, https://www.health.gov.au/sites/default/files/national-palliative-care-strategy2018.pdf (2018).

14. Smith V, Devane D, Begley CM, et al. Methodology in conducting a systematic review of systematic reviews of healthcare interventions. BMC Medical Research Methodology 2011; 11: 15. DOI: 10.1186/1471-2288-11-15.

15. Aromataris E, Fernandez R, Godfrey CM, et al. Summarizing systematic reviews: methodological development, conduct and reporting of an umbrella review approach. International Journal of Evidence-based Healthcare 2015; 13: 132-140.

16. Moher D, Liberati A, Tetzlaff J, et al. Preferred reporting items for systematic reviews and meta-analyses: the PRISMA statement. Annals of Internal Medicine 2009; 151: 264-269. DOI: 10.7326/0003-4819-151-4-200908180-00135.

17. Closs SJ, Dowding D, Allcock N, et al. Towards improved decision support in the assessment and management of pain for people with dementia in hospital: a systematic meta-review and observational study. Health Services and Delivery Research 2016; 4. 18. Liberati A, Altman DG, Tetzlaff J, et al. The PRISMA statement for reporting systematic reviews and meta-analyses of studies that evaluate health care interventions: explanation and elaboration. Journal of Clinical Epidemiology 2009; 62: e1-e34. DOI: 10.1016/j.jclinepi.2009.06.006.

19. Highet G, Crawford D, Murray SA, et al. Development and evaluation of the Supportive and Palliative Care Indicators Tool (SPICT): a mixed-methods study. BMJ Supportive and Palliative Care 2014; 4: 285. DOI: 10.1136/bmjspcare-2013-000488. 20. Whiting P, Savović J, Higgins JP, et al. ROBIS: a new tool to assess risk of bias in systematic reviews was developed. Journal of Clinical Epidemiology 2016; 69: 225-234. 
21. Popay J, Roberts H, Sowden A, et al. Guidance on the conduct of narrative synthesis in systematic reviews: a product from the ESRC Methods Programme. Lancaster: Lancaster University 2006; 10: 1018.4643.

22. Watanabe T and Kawaoka Y. Influenza virus-host interactomes as a basis for antiviral drug development. Current Opinion in Virology 2015; 14: 71-78. Review. DOI: 10.1016/j.coviro.2015.08.008.

23. Hebert MA, Brant R, Hailey D, et al. Potential and readiness for video-visits in rural palliative homecare: results of a multi-method study in Canada. Journal of Telemedicine and Telecare 2006; 12: 43-45.

24. Stern A, Valaitis R, Weir R, et al. Use of home telehealth in palliative cancer care: a case study. Journal of Telemedicine and Telecare 2012; 18: 297-300. DOI: 10.1258/jtt.2012.111201.

25. Odin P, Ray Chaudhuri K, Slevin JT, et al. Collective physician perspectives on non-oral medication approaches for the management of clinically relevant unresolved issues in Parkinson's disease: Consensus from an international survey and discussion program. Parkinsonism and Related Disorders 2015; 21: 1133-1144. Review. DOI: 10.1016/j.parkreldis.2015.07.020.

26. Widberg C, Wiklund B and Klarare A. Patients' experiences of eHealth in palliative care: an integrative review. BMC Palliative Care 2020; 19: 158. DOI: 10.1186/s12904-020-00667-1.

27. Johnston BM, McCauley R, McQuillan R, et al. Effectiveness and cost-effectiveness of out-of-hours palliative care: a systematic review. HRB Open Research 2020; 3: 9.

28. Portz JD, Elsbernd K, Plys E, et al. Elements of social convoy theory in mobile health for palliative care: Scoping review. Journal of Medical Internet Research 2020; 22 (1) (no pagination).

29. Allsop MJ, Taylor S, Mulvey MR, et al. Information and communication technology for managing pain in palliative care: a review of the literature. $B M J$ Supportive and Palliative Care 2015; 5: 481-489.

30. Hancock S, Preston $\mathrm{N}$, Jones $\mathrm{H}$, et al. Telehealth in palliative care is being described but not evaluated: a systematic review. BMC Palliative Care 2019; 18: 114. DOI: $10.1186 / \mathrm{s} 12904-019-0495-5$.

31. Lunney M, Lee R, Tang K, et al. Impact of telehealth interventions on processes and quality of care for patients with ESRD. American Journal of Kidney Diseases 2018; 72: 592-600.

32. Allsop MJ, Powell RA and Namisango E. The state of mHealth development and use by palliative care services in sub-Saharan Africa: a systematic review of the literature. BMJ Supportive and Palliative Care 2018; 8: 155. DOI: 10.1136/bmjspcare2015-001034.

33. Rogante M, Giacomozzi C, Grigioni M, et al. Telemedicine in palliative care: a review of systematic reviews. Annali dell'Istituto superiore di sanita 2016; 52: 434-442. 34. Head BA, Schapmire TJ and Zheng Y. Telehealth in palliative care: a systematic review of patient-reported outcomes. Journal of Hospice Palliative Nursing 2017; 19: 130-139.

35. Steindal SA, Nes AAG, Godskesen TE, et al. Patients' Experiences of Telehealth in Palliative Home Care: Scoping Review. Journal of Medical Internet Research 2020; 22. DOI: 10.2196/16218.

36. Bakitas M, Lyons KD, Hegel MT, et al. The project ENABLE II randomized controlled trial to improve palliative care for rural patients with advanced cancer: 
baseline findings, methodological challenges, and solutions. Palliat Support Care 2009; 7: 75-86. DOI: $10.1017 /$ S1478951509000108.

37. Dionne-Odom JN, Azuero A, Lyons KD, et al. Family Caregiver Depressive Symptom and Grief Outcomes From the ENABLE III Randomized Controlled Trial. Journal of Pain and Symptom Management 2016; 52: 378-385. DOI: https://doi.org/10.1016/j.jpainsymman.2016.03.014.

38. Bakitas M, Lyons KD, Hegel MT, et al. Effects of a Palliative Care Intervention on Clinical Outcomes in Patients With Advanced Cancer: The Project ENABLE II Randomized Controlled Trial. JAMA 2009; 302: 741-749. DOI: 10.1001/jama.2009.1198. 39. Bakitas MA, Tosteson TD, Li Z, et al. Early Versus Delayed Initiation of Concurrent Palliative Oncology Care: Patient Outcomes in the ENABLE III Randomized Controlled Trial. Journal of Clinical Oncology 2015; 33: 1438-1445. 2015/03/23. DOI: 10.1200/JC0.2014.58.6362.

40. Hoek PD, Schers HJ, Bronkhorst EM, et al. The effect of weekly specialist palliative care teleconsultations in patients with advanced cancer -a randomized clinical trial. BMC Medicine 2017; 15: 119. DOI: 10.1186/s12916-017-0866-9.

41. Kargar Jahromi M, Javadpour S, Taheri L, et al. Effect of Nurse-Led Telephone Follow ups (Tele-Nursing) on Depression, Anxiety and Stress in Hemodialysis Patients. Glob J Health Sci 2015; 8: 168-173. DOI: 10.5539/gjhs.v8n3p168.

42. Kornblith AB, Dowell JM, Herndon Ii JE, et al. Telephone monitoring of distress in patients aged 65 years or older with advanced stage cancer. Cancer 2006; 107: 27062714. DOI: $10.1002 /$ cncr.22296.

43. Kroenke K, Theobald D, Norton K, et al. The Indiana Cancer Pain and Depression (INCPAD) trial: Design of a telecare management intervention for cancer-related symptoms and baseline characteristics of study participants. General Hospital Psychiatry 2009; 31: 240-253. DOI: https://doi.org/10.1016/j.genhosppsych.2009.01.007.

44. Li J, Wang H, Xie H, et al. Effects of post-discharge nurse-led telephone supportive care for patients with chronic kidney disease undergoing peritoneal dialysis in China: a randomized controlled trial. Peritoneal Dialysis International 2014; 34: 278-288.

45. Demiris G, Parker Oliver D, Wittenberg-Lyles E, et al. A Noninferiority Trial of a Problem-Solving Intervention for Hospice Caregivers: In Person versus Videophone. Journal of Palliative Medicine 2012; 15: 653-660. DOI: 10.1089/jpm.2011.0488. 46. Chatwin M, Hawkins G, Panicchia L, et al. Randomised crossover trial of telemonitoring in chronic respiratory patients (TeleCRAFT trial). Thorax 2016; 71: 305311.

47. Cleeland CS, Wang XS, Shi Q, et al. Automated symptom alerts reduce postoperative symptom severity after cancer surgery: a randomized controlled clinical trial. Journal of Clinical Oncology 2011; 29: 994-1000. 2011/01/31. DOI: 10.1200/JCO.2010.29.8315.

48. Holmen H, Riiser K and Winger A. Home-Based Pediatric Palliative Care and Electronic Health: Systematic Mixed Methods Review. Journal of Medical Internet Research 2020; 22: e16248.

49. Jess M, Timm H and Dieperink KB. Video consultations in palliative care: A systematic integrative review. Palliative Medicine 2019; 33: 942-958. Review. DOI: 10.1177/0269216319854938.

50. Ostherr K, Killoran P, Shegog R, et al. Death in the digital age: A systematic review of information and communication technologies in end-of-life care. Journal of Palliative Medicine 2016; 19: 408-420. 
51. Zheng Y, Head BA and Schapmire TJ. A systematic review of Telehealth in palliative care: caregiver outcomes. Telemedicine e-Health 2016; 22: 288-294.

52. Sutherland AE, Stickland J and Wee B. Can video consultations replace face-toface interviews? Palliative medicine and the Covid-19 pandemic: rapid review. BMJ Supportive and Palliative Care 2020: bmjspcare-2020-002326. DOI: 10.1136/bmjspcare2020-002326.

53. Pinto S, Caldeira S and Martins JC. e-Health in palliative care: review of literature, Google Play and App Store. International Journal of Palliative Nursing 2017; 23: 394401. DOI: 10.12968/ijpn.2017.23.8.394.

54. Kroenke K, Theobald D, Wu J, et al. Effect of Telecare Management on Pain and Depression in Patients With Cancer: A Randomized Trial. JAMA 2010; 304: 163-171. DOI: $10.1001 /$ jama.2010.944.

55. Hanks GW, Robbins M, Sharp D, et al. The imPaCT study: a randomised controlled trial to evaluate a hospital palliative care team. British Journal of Cancer 2002; 87: 733739. DOI: $10.1038 /$ sj.bjc.6600522.

56. Johns SA, Kroenke K, Theobald DE, et al. Telecare Management of Pain and Depression in Patients With Cancer: Patient Satisfaction and Predictors of Use. The Journal of Ambulatory Care Management 2011; 34.

57. Kidd L, Cayless S, Johnston B, et al. Telehealth in palliative care in the UK: a review of the evidence. Journal of Telemedicine and Telecare 2010; 16: 394-402.

58. Berman SJ, Wada C, Minatodani D, et al. Home-based preventative care in highrisk dialysis patients: a pilot study. Telemedicine e-Health 2011; 17: 283-287.

59. Gallar P, Vigil A, Rodríguez I, et al. Two-year experience with telemedicine in the follow-up of patients in home peritoneal dialysis. Journal of Telemedicine and Telecare 2007; 13: 288-292.

60. Sicotte C, Moqadem K, Vasilevsky M, et al. Use of telemedicine for haemodialysis in very remote areas: the Canadian First Nations. Journal of Telemedicine and Telecare 2011; 17: 146-149.

61. Som A, Groenendyk J, An T, et al. Improving dialysis adherence for high risk patients using automated messaging: Proof of concept. Scientific Reports 2017; 7: 1-7. 62. Dhiliwal SR and Salins N. Smartphone applications in palliative homecare. Indian Journal of Palliative Care 2015; 21: 88.

63. Maudlin J, Keene J and Kobb R. A road map for the last journey: home telehealth for holistic end-of-life care. American Journal of Hospice and Palliative Medicine 2006; 23: 399-403.

64. Golinelli D, Boetto E, Carullo G, et al. Adoption of Digital Technologies in Health Care During the COVID-19 Pandemic: Systematic Review of Early Scientific Literature. Journal of medical Internet research 2020; 22: e22280.

65. Armstrong K. Review of after-hours service models: learnings for regional, rural and remote communities; Deeble Institute Issues Brief No. 15. In: Policy 0, (ed.). Deeble Institute for Health Policy Research, 2016.

66. Department of Health. After-hours palliative care framework. 2012. Melbourne, Victoria.

67. Care Innovations. How Virtual Reality Is Changing the Future of Healthcare Delivery, https://news.careinnovations.com/blog/how-virtual-reality-is-changing-thefuture-of-healthcare-delivery (2020).

68. Shaw J, Agarwal P, Desveaux L, et al. Beyond "implementation": digital health innovation and service design. npj Digital Medicine 2018; 1: 48. DOI: 10.1038/s41746018-0059-8. 
69. Calton BA, Rabow MW, Branagan L, et al. Top Ten Tips Palliative Care Clinicians Should Know About Telepalliative Care. Journal of Palliative Medicine 2019; 22: 981985.

70. Tieman JJ, Swetenham K, Morgan DD, et al. Using telehealth to support end of life care in the community: a feasibility study. BMC Palliative Care 2016; 15: 94. DOI: 10.1186/s12904-016-0167-7.

71. Roberts ET and Mehrotra A. Assessment of Disparities in Digital Access Among Medicare Beneficiaries and Implications for Telemedicine. JAMA Internal Medicine 2020. DOI: 10.1001/jamainternmed.2020.2666.

72. Analysis and Policy Observatory. Digital inclusion in Australia, https://digitalinclusionindex.org.au/about/about-digital-inclusion/ (2020, accessed 13 November 2020).

73. Parker S, Prince A, Thomas L, et al. Electronic, mobile and telehealth tools for vulnerable patients with chronic disease: a systematic review and realist synthesis. $B M J$ Open 2018; 8: e019192.

74. Lam K, Lu AD, Shi Y, et al. Assessing Telemedicine Unreadiness Among Older Adults in the United States During the COVID-19 Pandemic. JAMA Internal Medicine 2020. DOI: 10.1001/jamainternmed.2020.2671.

75. Fatehi F and Wootton R. Telemedicine, telehealth or e-health? A bibliometric analysis of the trends in the use of these terms. Journal of Telemedicine and Telecare 2012; 18: 460-464. DOI: 10.1258/jtt.2012.gth108.

76. Critical Appraisal Skills Programme (CASP). Critical Appraisal Skills Programme (CASP), https://casp-uk.net/casp-tools-checklists/ (2015).

77. Tricco AC, Lillie E, Zarin W, et al. PRISMA extension for scoping reviews (PRISMA-ScR): checklist and explanation. Annals of Internal Medicine 2018; 169: 467473.

78. Joanna Briggs Institute (JBI). Critical Appraisal Tools, https://joannabriggs.org/critical-appraisal-tools (2019).

79. Hawker S, Payne S, Kerr C, et al. Appraising the evidence: reviewing disparate data systematically. Qualitative Health Research 2002; 12: 1284-1299.

80. Wallace A, Croucher K, Quilgars D, et al. Meeting the challenge: developing systematic reviewing in social policy. Policy \& Politics 2004; 32: 455-470.

81. Hoffmann TC, Glasziou PP, Boutron I, et al. Better reporting of interventions: template for intervention description and replication (TIDieR) checklist and guide. $B M J$ $2014 ; 348$.

82. Higgins JP, Altman DG, Gøtzsche PC, et al. The Cochrane Collaboration's tool for assessing risk of bias in randomised trials. BMJ 2011; 343.

83. Padgett DK. Strategies for rigor. Qualitative Methods in Social Work Research, 2nd ed Thousand Oaks, CA: Sage Publications Inc 2008: 179-198.

84. Patton M. Qualitative research and evaluation methods 3rd Ed: Thousand Sage: Oaks. CA, 2002.

85. Shea BJ, Hamel C, Wells GA, et al. AMSTAR is a reliable and valid measurement tool to assess the methodological quality of systematic reviews. Journal of Clinical Epidemiology 2009; 62: 1013-1020. 
Table 1. Characteristics of reviews $(\mathrm{N}=16)$

\begin{tabular}{|c|c|c|}
\hline Characteristics & Number of studies (\%) & Citations \\
\hline \multicolumn{3}{|l|}{ Countries/regions ${ }^{\alpha}$} \\
\hline United Kingdom & $10(63)$ & $29-31,34,35,48-50,52,53$ \\
\hline USA & $10(63)$ & $26,29,31,34,35,49-53$ \\
\hline Australia & $8(50)$ & $26,35,48-53$ \\
\hline Canada & $8(50)$ & $26,31,34,35,49-52$ \\
\hline Japan & $7(44)$ & $29,31,35,49,50,52,53$ \\
\hline The Netherlands & $5(31)$ & $26,35,49,50,52$ \\
\hline Brazil & $4(25)$ & $35,49,52,53$ \\
\hline Sweden & $3(19)$ & $29,34,35$ \\
\hline India & $2(13)$ & 34,50 \\
\hline Norway & $2(13)$ & 29,53 \\
\hline Spain & $2(13)$ & 31,50 \\
\hline Portugal & $2(13)$ & 26,35 \\
\hline Switzerland & $1(6)$ & 26 \\
\hline Germany & $1(6)$ & 26 \\
\hline Iran & $1(6)$ & 31 \\
\hline China & $1(6)$ & 31 \\
\hline Korea & $1(6)$ & 50 \\
\hline Austria & $1(6)$ & 29 \\
\hline Hong Kong & $1(6)$ & 31 \\
\hline Germany & $1(6)$ & 29 \\
\hline Taiwan & $1(6)$ & 51 \\
\hline Sub-Saharan Africa & $1(6)$ & 32 \\
\hline New Zealand & $1(6)$ & 26 \\
\hline \multicolumn{3}{|l|}{ Age groups } \\
\hline All ages/ no restrictions on age & $11(69)$ & $29-34,49-53$ \\
\hline Adults $(18+)$ & $5(31)$ & $26-28,35,51$ \\
\hline Paediatrics & $1(6)$ & $48 *$ \\
\hline \multicolumn{3}{|l|}{ Primary Diagnosis ${ }^{\beta}$} \\
\hline Cancer & $10(63)$ & $26,28-30,32,34,35,49-51$ \\
\hline COPD & $5(31)$ & $26,28,30,35,49$ \\
\hline Heart failure & $4(25)$ & $28,30,34,51$ \\
\hline $\begin{array}{l}\text { Chronic kidney disease/ end-stage } \\
\text { renal disease }\end{array}$ & $3(19)$ & $30,31,34$ \\
\hline Life-limiting condition (broad) & $2(13)$ & 48,49 \\
\hline Cystic fibrosis & $2(13)$ & 30,35 \\
\hline Multiple sclerosis & $2(13)$ & 26,35 \\
\hline Amyotrophic lateral sclerosis & $2(13)$ & 26,35 \\
\hline Respiratory failure (non-COPD) & $1(6)$ & 30 \\
\hline HIV/AIDS & $1(6)$ & 32 \\
\hline Advanced dementia & $1(6)$ & 30 \\
\hline Motor neurone disease & $1(6)$ & 30 \\
\hline \multicolumn{3}{|l|}{ Virtual care strategy (DHT use) } \\
\hline Scheduled review (video consultation) & $12(75)$ & $26,30,31,33-35,48-53$ \\
\hline $\begin{array}{l}\text { Scheduled review (telephone } \\
\text { consultation) }\end{array}$ & $9(56)$ & $26,31,33-35,48,50,51,53$ \\
\hline Self-management (mobile applications) & $8(50)$ & $28,32-35,48,50,53$ \\
\hline Symptom management (RPM) & $8(50)$ & $26,29-31,33,35,50,53$ \\
\hline $\begin{array}{l}24 \text { hour support (telephone advice } \\
\text { lines) }\end{array}$ & $5(31)$ & $27,30,32,33,50$ \\
\hline $\begin{array}{l}\text { Patient/carer information } \\
\text { (websites/internet) }\end{array}$ & $3(19)$ & $33,34,50$ \\
\hline
\end{tabular}




\begin{tabular}{|c|c|c|}
\hline $\begin{array}{l}\text { Symptom management, psychosocial } \\
\text { support (SMS text messaging) }\end{array}$ & $2(13)$ & 32,50 \\
\hline $\begin{array}{l}\text { Communication with patients/ health } \\
\text { professionals (Email and/or Faxing) }\end{array}$ & $2(13)$ & 50,53 \\
\hline $\begin{array}{l}\text { Symptom management (PalmPilot / } \\
\text { pen tablets) }\end{array}$ & $2(13)$ & 33,50 \\
\hline \multicolumn{3}{|l|}{ Outcomes measured } \\
\hline Health-related outcomes & & \\
\hline $\begin{array}{l}\text { Patient-physician communication/ } \\
\text { relationship }\end{array}$ & $4(25)$ & $26,33,50,53$ \\
\hline $\begin{array}{l}\text { Clinical health-related outcomes } \\
\text { (broad) }\end{array}$ & $3(19)$ & $33,35,48$ \\
\hline Symptom management/ reduction & $3(19)$ & $26,33,34$ \\
\hline Self-reported health outcomes (broad) & $2(13)$ & 35,48 \\
\hline Quality of life & $2(13)$ & 33,34 \\
\hline $\begin{array}{l}\text { Patient anxiety/depression/ } \\
\text { psychological wellbeing }\end{array}$ & $2(13)$ & 31,34 \\
\hline Pain assessment / management & $2(13)$ & 29,33 \\
\hline Caregiver quality of life & $1(6)$ & 51 \\
\hline Caregiver mood/anxiety & $1(6)$ & 51 \\
\hline $\begin{array}{l}\text { Caregiver perception of pain } \\
\text { management }\end{array}$ & $1(6)$ & 33 \\
\hline Physical function & $1(6)$ & 31 \\
\hline Caregiver burden & $1(6)$ & 51 \\
\hline Family functioning & $1(6)$ & 51 \\
\hline Social support & $1(6)$ & 51 \\
\hline $\begin{array}{l}\text { Surrogate measures e.g. blood } \\
\text { pressure, disease-related process } \\
\text { measures }\end{array}$ & $1(6)$ & 31 \\
\hline \multicolumn{3}{|l|}{ Health service utilisation } \\
\hline $\begin{array}{l}\text { Hospital/ED admissions and/or } \\
\text { readmissions }\end{array}$ & $3(19)$ & $30,31,34$ \\
\hline \multicolumn{3}{|l|}{ Intervention related outcomes } \\
\hline $\begin{array}{l}\text { Patient and/or carer perceptions / user } \\
\text { satisfaction/ satisfaction with care / } \\
\text { experience measures }\end{array}$ & $6(38)$ & $26,27,30,31,34,35$ \\
\hline General usage/usability & $5(31)$ & $26,30,32,52,53$ \\
\hline Cost / Cost-effectiveness & $5(31)$ & $27,30,33,34,53$ \\
\hline Efficacy/effectiveness & $4(25)$ & $27,31,33,50$ \\
\hline $\begin{array}{l}\text { Advantages/disadvantages of } \\
\text { intervention }\end{array}$ & $3(19)$ & $33,49,53$ \\
\hline Feasibility of intervention & $2(13)$ & 26,33 \\
\hline Barriers/facilitators of intervention & $2(13)$ & 49,53 \\
\hline $\begin{array}{l}\text { Features for family support and } \\
\text { caregiving functionality }\end{array}$ & $1(6)$ & 28 \\
\hline Compatibility & $1(6)$ & 53 \\
\hline $\begin{array}{l}\text { Patient acceptance/compliance of } \\
\text { intervention }\end{array}$ & $1(6)$ & 33 \\
\hline Sense of safety and patient security & $1(6)$ & 26 \\
\hline $\begin{array}{l}\text { Level of Digital Service Standard } \\
\text { compliance }\end{array}$ & $1(6)$ & 30 \\
\hline Intended location of use & $1(6)$ & 32 \\
\hline Stage of development & $1(6)$ & 32 \\
\hline
\end{tabular}

COPD, chronic obstructive pulmonary disease; DHT, digital health technology; ED, emergency department; HIV/AIDS, Human Immunodeficiency Virus / Acquired Immunodeficiency Syndrome RPM, remote patient monitoring; SMS, short message service; USA, United Stated of America 
${ }^{\alpha}$ Rogante et al. ${ }^{33}$ and Portz et al. ${ }^{28}$ did not report on the country of origin of their included studies. Johnston et al. included no studies.

${ }^{\beta}$ Sutherland et al. ${ }^{52}$ did not provide information on the primary diagnoses of patients in included studies.

*Holmen et al. ${ }^{48}$ also included studies with adult populations 
Table 2. Summary table of included reviews

\begin{tabular}{|c|c|c|c|c|c|c|c|c|}
\hline $\begin{array}{l}\text { Source (Years } \\
\text { covered by review) }\end{array}$ & Aim & $\begin{array}{l}\text { Design/ } \\
\text { Follows } \\
\text { PRISMA/Quality } \\
\text { appraisal }\end{array}$ & $\begin{array}{l}\text { Countries / } \\
\text { Regions }\end{array}$ & $\begin{array}{l}\text { Included studies (N) } \\
\text { Type/level of evidence }\end{array}$ & $\begin{array}{l}\text { Participants } \\
\text { (N)/ condition }\end{array}$ & Intervention & Outcomes & Conclusions \\
\hline $\begin{array}{l}\text { Widberg et al. } \\
2022^{26} \\
(2014-2019)\end{array}$ & $\begin{array}{l}\text { To describe the } \\
\text { evidence regarding } \\
\text { patients' } \\
\text { experiences of } \\
\text { eHealth in palliative } \\
\text { care. }\end{array}$ & $\begin{array}{l}\text { Integrative review } \\
\text { Thematic analysis } \\
\text { YES - PRISMA }{ }^{16} \\
\text { YES - Quality appraisal: } \\
\text { CASP Tools }{ }^{75}\end{array}$ & $\begin{array}{l}\text { Australia, New } \\
\text { Zealand, Canada, } \\
\text { the Netherlands, } \\
\text { Portugal, } \\
\text { Switzerland, } \\
\text { Germany, USA }\end{array}$ & 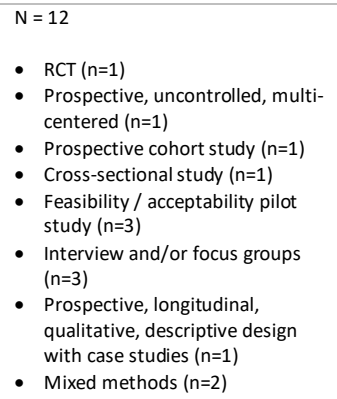 & $\begin{array}{l}\mathrm{N}=397 \\
\text { - Cancer } \\
\text { - COPD } \\
\text { - Amyotrophic lateral } \\
\text { sclerosis (ALS) } \\
\text { - Multiple sclerosis } \\
\text { (MS) }\end{array}$ & $\begin{array}{l}\text { eHealth: } \\
\text { - Telephone } \\
\text { consultation } \\
\text { - Video consultation } \\
\text { - RPM }\end{array}$ & $\begin{array}{l}\text { - Patient experience } \\
\text { Usability/feasibility of } \\
\text { e elealth applications } \\
\text { - Symptom control and } \\
\text { individualized care through } \\
\text { elealth applications } \\
\text { - Sense of security and patient } \\
\text { safety }\end{array}$ & $\begin{array}{l}\text { - Patients' experiences were that } \\
\text { eHealth promoted individualized care, } \\
\text { sense of security, better symptom } \\
\text { management and participation in care. } \\
\text { - Communication was facilitated by the } \\
\text { inherent flexibility provided by } \\
\text { technology. }\end{array}$ \\
\hline $\begin{array}{l}\text { Portz et al. } 202028 \\
\text { (2010-2019) }\end{array}$ & $\begin{array}{l}\text { To describe the } \\
\text { inclusion and } \\
\text { functionality of } \\
\text { family, social } \\
\text { relationships, and } \\
\text { caregivers in } \\
\text { palliative care } \\
\text { mobile apps. }\end{array}$ & $\begin{array}{l}\text { Systematic scoping } \\
\text { review } \\
\text { Descriptive analysis } \\
\text { YES -PRISMA: uses } \\
\text { extension for Scoping } \\
\text { Reviews }^{76} \\
\text { NO - Quality appraisal }\end{array}$ & Not reported & $\begin{array}{l}N=10 \\
\text { - Protocol }(n=4) \\
\text { - Pilot }(n=4) \\
\text { - Descriptive survey }(n=1) \\
n=22 \text { (commercial apps) }\end{array}$ & $\begin{array}{l}P^{N A} \text { Cancer } \\
: \text { HF } \\
- \text { COPD }\end{array}$ & $\begin{array}{l}\text { mHealth: } \\
\text { - Mobile apps }\end{array}$ & $\begin{array}{l}\text { - Palliative care element } \\
\text { Target user } \\
\text { - Features for family support } \\
\text { and caregiving functionality }\end{array}$ & $\begin{array}{l}\text { - There is an emerging presence of apps } \\
\text { for patients and social convoys } \\
\text { receiving palliative care. } \\
\text { - Additional research is needed for apps } \\
\text { that embrace a team approach to } \\
\text { information sharing, target family- and } \\
\text { caregiver-specific issues, promote } \\
\text { access to palliative care, and are } \\
\text { comprehensive of palliative needs. }\end{array}$ \\
\hline $\begin{array}{l}\text { Johnston et al. } 2020 \\
27 \\
(1998-2018)\end{array}$ & $\begin{array}{l}\text { To determine the } \\
\text { effect of out-of- } \\
\text { hours specialist and } \\
\text { generalist palliative } \\
\text { care services on } \\
\text { patient and family/ } \\
\text { caregiver outcomes, } \\
\text { and on costs and } \\
\text { cost-effectiveness? }\end{array}$ & $\begin{array}{l}\text { Systematic review } \\
\text { Descriptive analysis } \\
\text { YES - PRISMA }{ }^{16} \\
\text { YES - Quality appraisal: } \\
\text { CASP Tools } \\
\end{array}$ & $N A$ & $\begin{array}{l}\mathrm{N}=0 \\
\text { - RCTs } \\
\text { - Prospective/ retrospective } \\
\text { cohort studies } \\
\text { - Before-and-after studies } \\
\text { - Economic evaluations } \\
\text { - } \text { Qualitative/descriptive studies } \\
\text { Piludies }\end{array}$ & $N A$ & $N A$ & $\begin{array}{l}\text { - Patient and family/caregiver } \\
\text { outcomes } \\
\text { - Costs and cost-effectiveness }\end{array}$ & $\begin{array}{l}\text { - One study was identified in the peer- } \\
\text { reviewed literature, but was deemed } \\
\text { of insufficient quality. } \\
\text { - The importance of integrated, } 24 \text {-hour } \\
\text { care for people in line with a palliative } \\
\text { care approach is not reflected in the } \\
\text { literature, which lacks evidence on the } \\
\text { effects of interventions provided } \\
\text { outside typical working hours. }\end{array}$ \\
\hline $\begin{array}{l}\text { Sutherland et al. } \\
2020^{52} \text { eoorted) } \\
\text { (Not reported }\end{array}$ & $\begin{array}{l}\text { To identify all } \\
\text { potentially relevant } \\
\text { research about } \\
\text { video consultations } \\
\text { in palliative care. }\end{array}$ & $\begin{array}{l}\text { Rapid review of } \\
\text { systematic reviews } \\
\text { Narrative synthesis } \\
\text { NO - PRISMA (not } \\
\text { explicit) } \\
\text { NO - Quality appraisal }\end{array}$ & $\begin{array}{l}\text { USA, Australia, } \\
\text { Canada, } \\
\text { Netherlands, UK, } \\
\text { Brazil, Japan }\end{array}$ & $\begin{array}{l}N=34 \\
\text { Level 1a Systematic Reviews, } \\
\text { including: } \\
\text { - Quantitative }(n=10) \text {, including } \\
\text { one } R C T(n=1) \text { and case studies } \\
(n=5) \\
\text { - Mixed methods ( } n=14) \\
\text { - Qualitative }(n=10)\end{array}$ & $\begin{array}{l}\mathrm{N}=2345 \text { patients with } \\
\text { palliative care needs } \\
\mathrm{N}=549 \text { carers } / \mathrm{NOK} \\
\mathrm{N}=252 \mathrm{HPs}\end{array}$ & - Video consultation & $\begin{array}{l}\text { Did not stipulate primary and } \\
\text { secondary outcomes } \\
\text { - Included studies focused on any } \\
\text { outcome and general usage }\end{array}$ & $\begin{array}{l}\text { - Video consultations are an effective, } \\
\text { accessible, acceptable and cost- } \\
\text { effective method of service delivery. } \\
\text { - Organisations must ensure software is } \\
\text { simple, effective, reliable and safe, } \\
\text { with the highest level of security for } \\
\text { confidentiality. }\end{array}$ \\
\hline
\end{tabular}




\begin{tabular}{|c|c|c|c|c|c|c|c|c|}
\hline $\begin{array}{l}\text { Steindal et al. } 2020 \\
35 \\
(2000-2018)\end{array}$ & $\begin{array}{l}\text { To map and assess } \\
\text { the use of telehealth } \\
\text { for patients in } \\
\text { palliative home } \\
\text { care. }\end{array}$ & $\begin{array}{l}\text { Systematic scoping } \\
\text { review } \\
\text { Inductive thematic } \\
\text { analysis } \\
\text { YES - PRSIMA: uses } \\
\text { extension for Scoping } \\
\text { Reviews }^{76} \\
\text { NO - Quality appraisal }\end{array}$ & $\begin{array}{l}\text { Australia, Brazil, } \\
\text { Canada, Japan, } \\
\text { Netherlands, } \\
\text { Portugal, Sweden, } \\
\text { UK, USA. }\end{array}$ & $\begin{array}{ll} & N=22 \\
& \text { RCTs (n=3) } \\
\text { - } & \text { Quantitative (n=7) } \\
\text { - } & \text { Mase studies (n=3) } \\
\text { - } & \text { Qualititative (n=2) }\end{array}$ & $\begin{array}{l}\mathrm{N}=644 \text { patients with } \\
\text { palliative care needs as } \\
\text { a result of: } \\
\text { - copD } \\
\text { Cystic fibrosis } \\
\text { - Cancer } \\
\text { - Multiple sclerosis } \\
\text { Amyotrophic lateral } \\
\text { sclerosis } \\
\text { Sample range: } 2 \text { - } 187\end{array}$ & $\begin{array}{l}\text { Telehealth follow-up: } \\
\text { - Video } \\
\text { - Teleconsultation } \\
\text { - Webinar technology } \\
\text { : Mobile phones } \\
\text { - PDs } \\
\text { Apps on } \\
\text { smartphones, } \\
\text { tablets or } \\
\text { computers } \\
\text { - Self-monitoring }\end{array}$ & $\begin{array}{l}\text { - Patient reported subjective } \\
\text { and objective outcomes } \\
\text { - Patient experience }\end{array}$ & $\begin{array}{l}\text { - Telehealth in palliative home care } \\
\text { seems to be feasible, improving access } \\
\text { to health care professionals at home } \\
\text { and enhancing feelings of security and } \\
\text { safety. } \\
\text { - The visual features of telehealth seem } \\
\text { to allow a genuine relationship with } \\
\text { health profossionals. However, there } \\
\text { are contradicting results on whether } \\
\text { the use of telehealth improves } \\
\text { burdensome symptoms and QOL. }\end{array}$ \\
\hline $\begin{array}{l}\text { Holmen et al. } 2020 \\
\text { 48 } \\
\text { (2012-2016) }\end{array}$ & $\begin{array}{l}\text { Identify and review } \\
\text { the use of eHealth } \\
\text { and communication } \\
\text { and support home- } \\
\text { based paediatric } \\
\text { palliative care; } \\
\text { appraise } \\
\text { methodological } \\
\text { quality of published } \\
\text { research. }\end{array}$ & $\begin{array}{l}\text { Systematic mixed } \\
\text { methods review } \\
\text { Thematic analysis (line- } \\
\text { by-line coding) and } \\
\text { convergent synthesis } \\
\text { YES - PRISMA }{ }^{16} \\
\text { YES - Quality appraisal: } \\
\text { Joanna Briggs Institute } \\
\text { using Standardised } \\
\text { checklists for primary } \\
\text { studies }{ }^{7}\end{array}$ & Australia, UK & $\begin{array}{l}\mathrm{N}=7 \\
\text { All studies evaluated an } \\
\text { intervention. One study aimed for a } \\
\text { controlled design but ended } \\
\text { recruitment prematurely because of } \\
\text { unanticipated patient deaths. }\end{array}$ & $\begin{array}{l}\text { Not reported } \\
\text { Paediatric palliative } \\
\text { care patients with: } \\
\text { - life-limiting } \\
\text { conditions }\end{array}$ & $\begin{array}{l}\text { eHealth systems } \\
\text { allowing 2-way } \\
\text { communication: } \\
\text { - Video conference } \\
\text { - Telephone } \\
\text { - Web-based tool }\end{array}$ & $\begin{array}{l}\text { - Health-elated outcomes } \\
\text { (self-reported and objective } \\
\text { measures }\end{array}$ & $\begin{array}{l}\text { - Regardless of technology, children } \\
\text { need an individual approach. } \\
\text { - Child and family preferences as well as } \\
\text { the former's care needs can guide the } \\
\text { tailoring of eHealth technology. } \\
\text { - Some HPs preferred videoconferences } \\
\text { to telephone calls. } \\
\text { - HPs perceived using devices in addition } \\
\text { to the burden of having a child with } \\
\text { palliative care needs seemed } \\
\text { demanding of the parents. }\end{array}$ \\
\hline $\begin{array}{l}\text { Jess et al. } 20199^{49} \\
(2005-2018)\end{array}$ & $\begin{array}{l}\text { To analyse the } \\
\text { barriers and } \\
\text { facilitators of video } \\
\text { consultations in } \\
\text { general and } \\
\text { specialised palliative } \\
\text { care. }\end{array}$ & $\begin{array}{l}\text { Systematic integrative } \\
\text { review } \\
\text { Narrative synthesis } \\
\text { YES - PRISMA }{ }^{16} \\
\text { YES - Quality Appraisal: } \\
\text { according to Hawker et. }_{\text {al }^{78}}\end{array}$ & $\begin{array}{l}\text { USA } \\
\text { Australia, Canada, } \\
\text { Netherlands, UK, } \\
\text { Brazil, Japan }\end{array}$ & $\begin{array}{l}N=39 \\
\text { - } \quad \text { Quantitative }(n=10) \\
\text { - Case studies }(n=5) \\
\text { - } \text { Mixed methods }(n=14) \\
\text { Qualitative }(n=10)\end{array}$ & $\begin{array}{l}n=2345 \text { patients } \\
n=549 \text { relatives } \\
n=252 \text { HPs } \\
\text { Palliative care patients } \\
\text { with life-threatening } \\
\text { illnesses: } \\
\text { - Cancer } \\
\text { - COPD }\end{array}$ & - Video consultation & $\begin{array}{l}\text { - Advantages/disadvantages } \\
\text { Barriers/facilitators }\end{array}$ & $\begin{array}{l}\text { - Video consultations in palliative care } \\
\text { mainly focused on specialised palliative } \\
\text { care settings in high-income countries } \\
\text { and patients with a cancer diagnosis. } \\
\text { - It is important to include the } \\
\text { perspective of patients and relatives as } \\
\text { well as HPs when evaluating the use of } \\
\text { video consultations in palliative care. }\end{array}$ \\
\hline $\begin{array}{l}\text { Hancock et al. } 2019 \\
30 \\
\text { (2010-2018) }\end{array}$ & $\begin{array}{l}\text { To describe the } \\
\text { current use of } \\
\text { telehealth in } \\
\text { palliative care in the } \\
\text { UK and evaluate } \\
\text { telehealth initiatives } \\
\text { against a digital } \\
\text { service standard. }\end{array}$ & $\begin{array}{l}\text { Systematic review } \\
\text { Thematic synthesis } \\
\text { YES - PRISMA }{ }^{16} \\
\text { YES - Quality Appraisal } \\
\text { according to Wallace. } \\
\text { et al }{ }^{79}\end{array}$ & UK specific & 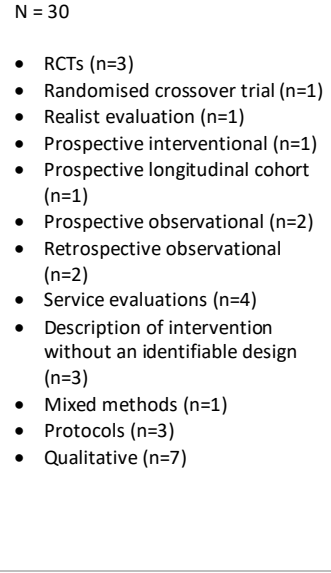 & $\begin{array}{l}\mathrm{n}=6617 \text { patients/ } \\
\text { caregivers } \\
\mathrm{n}=298 \mathrm{HPs} \\
\text { Sample range: } 3-3594 \\
\text { Patients with palliative } \\
\text { care needs: } \\
\text { - COPD } \\
\text { - Respiratory failure } \\
\text { - Renal failure } \\
\text { Chronic kidney } \\
\text { - } \mathrm{HF} \\
\text { - Cancer } \\
\text { - Metastatic breast } \\
\text { - cancer } \\
\text { - Motor neurone } \\
\text { - cysease } \\
\text { - Advanced fibrosis } \\
\text { - Adementia }\end{array}$ & $\begin{array}{l}\text { Telehealth: } \\
\text { - RPM } \\
\text { - Digital support via } \\
\text { telephone or video }\end{array}$ & $\begin{array}{l}\text { - General usage in palliative } \\
\text { care } \\
\text { - Level of Digital Service } \\
\text { Standard compliance } \\
\text { - Acute or emergency services } \\
\text { use } \\
\text { - Cost-effectiveness } \\
\text { - User perception }\end{array}$ & $\begin{array}{l}\text { - Although there is growth of telehealth } \\
\text { services, there remains a lack of } \\
\text { evaluation and robust studd design } \\
\text { limiting conclusions regarding the } \\
\text { clinical application of telehealth in } \\
\text { palliative care. } \\
\text { - There is insufficient evidence to } \\
\text { appreciate benefit of teleeealth on } \\
\text { access to emergency care. } \\
\text { - Future work is needed to evaluate the } \\
\text { use of telehealth in palliative care and } \\
\text { improve telehealth design in line with } \\
\text { digital service standards. }\end{array}$ \\
\hline
\end{tabular}




\begin{tabular}{|c|c|c|c|c|c|c|c|c|}
\hline $\begin{array}{l}\text { Allsop et al. } 2018^{32} \\
(1990-2015)\end{array}$ & $\begin{array}{l}\text { To identify the } \\
\text { development and } \\
\text { use of mHealth in } \\
\text { palliative care } \\
\text { services in Sub- } \\
\text { Saharan Africa. }\end{array}$ & $\begin{array}{l}\text { Systematic review } \\
\text { Descriptive analysis } \\
\text { YES - PRISMA }{ }^{16} \\
\text { NO-Quality appraisal }\end{array}$ & $\begin{array}{l}\text { Sub-Saharan Africa: } \\
\text { Kenya, Malawi, } \\
\text { Uganda, Nigeria, }\end{array}$ & $\begin{array}{l}\mathrm{N}=5 \\
\text { - Pre-test and post-test } \\
\text { questionnaires to evaluate an } \\
\text { education intervention for HPs } \\
\text { (n=1) } \\
\text { - Descriptive analyysis of data } \\
\text { captured from patient contact } \\
\text { with HPs using a mobile phone } \\
\text { alongside findings from } \\
\text { interviews with patients about } \\
\text { experience using mobile phones } \\
\text { as part of their care }(n=1) \\
\text { - Rapid evaluation }(n=1) \\
\text { - Questionnaire }(n=1) \\
\text { - Interviews }(n=1)\end{array}$ & $\begin{array}{l}\mathrm{n}=74 \text { HPs } \\
\mathrm{n}=1176 \text { patients } \\
\text { Two studies did not } \\
\text { provide sample } \\
\text { number/data } \\
\text { Patients with palliative } \\
\text { care needs and their } \\
\text { carers/families: } \\
\text { - Cancer } \\
\text { - HIV / AIDS }\end{array}$ & $\begin{array}{l}\text { mHealth: } \\
\text { : Mobile phones } \\
\text { : RPM device } \\
\text { - Personal digital } \\
\text { assistants } \\
\text { - Wireless devices } \\
\text { - Telephone } \\
\text { SMS text messaging }\end{array}$ & $\begin{array}{l}\text { - Regions and use of mHealth } \\
\text { - Intended location of use } \\
\text { Stage of development }\end{array}$ & $\begin{array}{l}\text { - Existing mHealth interventions for } \\
\text { palliativive care in sub--saharan Africa } \\
\text { are limited in number, and are } \\
\text { developed for use at the palliative } \\
\text { treatment, guidance and coordination } \\
\text { stage of care provision. } \\
\text { - Levels of detail about development } \\
\text { and structure of interventions are low. }\end{array}$ \\
\hline $\begin{array}{l}\text { Lunney et al. } 2018^{31} \\
(2007-2017)\end{array}$ & $\begin{array}{l}\text { Telehealth } \\
\text { interventions on } \\
\text { processes and } \\
\text { quality of care for } \\
\text { patients with ESRD }\end{array}$ & $\begin{array}{l}\text { Systematic review } \\
\text { Descriptive synthesis } \\
\text { NO - PRISMA (although } \\
\text { provides a PRISMA } \\
\text { flowchart) } \\
\text { NO - Quality appraisal } \\
\text { (used the TIDieR } \\
\text { checklist } 80 \text { for } \\
\text { reporting) }\end{array}$ & $\begin{array}{l}\text { US, Hong Kong, UK, } \\
\text { Spain, Japan, Iran, } \\
\text { China, Canada }\end{array}$ & $\begin{array}{l}N=11 \\
\text { - Randomised trials }(n=7) \\
\text { Cohort studies }(n=3)\end{array}$ & $\begin{array}{l}\mathrm{N}=2611 \\
\text { Sample range: } 11-135 \\
\text { - ESRD }\end{array}$ & $\begin{array}{l}\text { Telehealth: } \\
\text { : Telephone } \\
\text { - RPM } \\
\text { - Video conference }\end{array}$ & $\begin{array}{l}\text { - Effectiveness } \\
\text { Hospitalisation; patient- } \\
\text { reported outcomes: (physical } \\
\text { and mental status) } \\
\text { - Experience measures } \\
\text { - Surrogate measures e.g. BP; } \\
\text { ESRD process measures }\end{array}$ & $\begin{array}{l}\text { - Study populations, modes of telehealth } \\
\text { delivery and outcomes evaluated } \\
\text { varied substantially between studies. } \\
\text { - Two studies examined telehealth } \\
\text { interventions versus standard ESRD } \\
\text { care, demonsstrating mixed results on } \\
\text { processes of care, no differences in } \\
\text { laboratory surrogate markers of ESRD } \\
\text { care, and reduced or similar rates of } \\
\text { hospitalisation. } \\
\text { - Eight studies evaluated the addition of } \\
\text { telehealth to usual care and } \\
\text { demonstrated no significant } \\
\text { improvements in processes of care or } \\
\text { surrogate laboratory measures, } \\
\text { variable impacts on hospitalisation } \\
\text { rates, and mixed impacts on some } \\
\text { domains of QOL, including } \\
\text { improvement in mental health. }\end{array}$ \\
\hline $\begin{array}{l}\text { Head et al. } 2017^{34} \\
(2006-2016)\end{array}$ & $\begin{array}{l}\text { Summarise findings } \\
\text { related to patient- } \\
\text { reported outcomes } \\
\text { in published results } \\
\text { of palliative } \\
\text { telehealth } \\
\text { interventions. }\end{array}$ & $\begin{array}{l}\text { Systematic review } \\
\text { Descriptive analysis } \\
\text { YES - PRISMA }{ }^{16} \\
\text { YES - Quality appraisal: } \\
\text { Quantitative -Cochrane } \\
\text { Collaboration tool } \\
\text { Qualitative - a checklist } \\
\text { was used to evaluate } \\
\text { trustworthiness of the } \\
\text { methodology } y^{22,83}\end{array}$ & $\begin{array}{l}\text { India, Canada, UK, } \\
\text { Sweden, US }\end{array}$ & 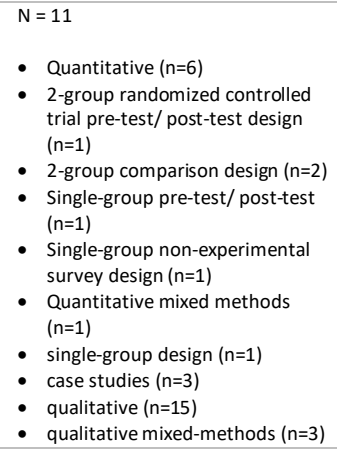 & $\begin{array}{l}n=1741 \text { patients } \\
n=9 \text { HPs } \\
\text { Sample range: } 1-1352 \\
\text { Patients receiving } \\
\text { palliative or ELC care } \\
\text { for a serious condition } \\
\text { (i.e. advanced/end- } \\
\text { stage disease): } \\
\text { C Cancer } \\
\text { - ESRD } \\
\text { - HF }\end{array}$ & $\begin{array}{l}\text { Telehealth: } \\
\text { - Videophones } \\
\text { - Telephone } \\
\text { - Computer programs } \\
\text { with internet access } \\
\text { - Smart phone } \\
\text { applications }\end{array}$ & $\begin{array}{l}\text { - QOL } \\
\text { - Symptom management } \\
\text { - Patient satisfaction } \\
\text { - Depression/anxiety } \\
\text { - } \text { Cospital visits } \\
\text { - Cost }\end{array}$ & $\begin{array}{l}\text { - Support for positive patient outcomes } \\
\text { in palliative telehealth interventions } \\
\text { was weak. } \\
\text { - However, all studies but one found } \\
\text { positive results to support the } \\
\text { intervention. Results across studies } \\
\text { were also variable. }\end{array}$ \\
\hline
\end{tabular}




\begin{tabular}{|c|c|c|c|c|c|c|c|c|}
\hline $\begin{array}{l}\text { Pinto et al. 2017 } \\
\text { (up until 2016) }\end{array}$ & $\begin{array}{l}\text { To analyse the use } \\
\text { of e-Health } \\
\text { technologies and } \\
\text { mobile apps in } \\
\text { palliative care. }\end{array}$ & $\begin{array}{l}\text { Systematic review } \\
\text { Descriptive analysis } \\
\text { NO-PRISMA (not } \\
\text { explicit) } \\
\text { NO- Quality appraisal }\end{array}$ & $\begin{array}{l}\text { US, Australia, UK, } \\
\text { Norway, Japan, } \\
\text { Brazil }\end{array}$ & $\begin{array}{l}\mathrm{N}=25 \text { (studies) } \\
\text { - } \quad \text { RCT (n=4) } \\
\text { - Cost minimization analysis (n=1) } \\
\text { - Evaluation study (n=1) } \\
\text { - Feasibility study }(n=3) \\
\text { - Pilot study }(n=6) \\
\text { - Case series }(n=3) \\
\text { - Case study }(n=3) \\
\text { - Mixed methods }(n=3) \\
\text { - Interviews }(n=1) \\
n=40 \text { (Apps) }\end{array}$ & $\begin{array}{l}\text { Not reported } \\
\text { - Palliative care }\end{array}$ & $\begin{array}{l}\text { eHealth technologies: } \\
\text { : Video conferencing } \\
\text { : Telephone } \\
\text { : RPM } \\
\text { - } \text { E-mabile apps } \\
\text { E-mail }\end{array}$ & $\begin{array}{l}\text { - Use } \\
\text { Availability of mobile apps } \\
\text { Strengths, weaknesses, } \\
\text { opportunities and threats of } \\
\text { these technologies } \\
\text { - Compatibility and charges for } \\
\text { the app } \\
\text { - Main objective of the app } \\
\text { - Level of communication }\end{array}$ & $\begin{array}{l}\text { - Teleconsultation is the principal e- } \\
\text { Health technology. } \\
\text { Mobile applications focused on } \\
\text { communication, drugs, tools/clinical } \\
\text { guidelines, hospice, symptom } \\
\text { management and palliative care } \\
\text { information. }\end{array}$ \\
\hline $\begin{array}{l}\text { Ostherr et al. } 2016 \\
\text { so } \\
(1997-2013)\end{array}$ & $\begin{array}{l}\text { To identify the ICTs } \\
\text { being used in EOL } \\
\text { communication. The } \\
\text { secondary objective } \\
\text { was to compare the } \\
\text { effectiveness of } \\
\text { different ICTs in EOL } \\
\text { communication. }\end{array}$ & $\begin{array}{l}\text { Systematic review } \\
\text { Descriptive analysis } \\
\text { YES - PRISMA }{ }^{16} \\
\text { YES - Quality Appraisal: } \\
\text { Cochrane } \\
\text { Collaboration's Tool } \\
\text { 81 }\end{array}$ & $\begin{array}{l}\text { USA, Canada, Spain, } \\
\text { UK, Netherlands, } \\
\text { Australia, Korea, } \\
\text { Japan, India }\end{array}$ & 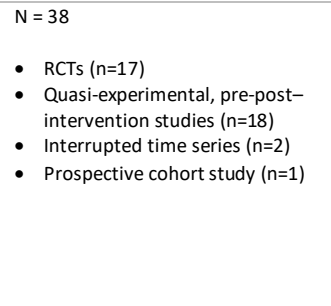 & $\begin{array}{l}\mathrm{N}=14488 \\
\text { One study did not } \\
\text { report sample size } \\
\text { Sample range: } 15- \\
4742 \\
\text { Patients at EOL: } \\
\text { - Cancer }\end{array}$ & $\begin{array}{l}\text { ICTs: } \\
\text { : video } \\
\text { : website } \\
\text { : telephone } \\
\text { :-mail } \\
\text { : } \text { RPM } \\
\text { IPternet search } \\
\text { : Compact disc } \\
\text { : } \text { Fax } \\
\text { : } \text { PalmPilot } \\
\text { SMS text messaging }\end{array}$ & $\begin{array}{l}\text { - Efficacy } \\
\text { - Impact or effectiveness } \\
\text { - Doctor-patient } \\
\text { communication }\end{array}$ & $\begin{array}{l}\text { - ICTs were most commonly used to } \\
\text { provide information or education, } \\
\text { serve as decision aids, promote ACP, } \\
\text { and relieve physical symptom distress. }\end{array}$ \\
\hline $\begin{array}{l}\text { Rogante et al. } 2016 \\
{ }_{33} \text { (2007-2014) }\end{array}$ & $\begin{array}{l}\text { To evaluate the } \\
\text { quality of systematic } \\
\text { reviews on } \\
\text { telemedicine } \\
\text { applications in } \\
\text { palliative care. }\end{array}$ & 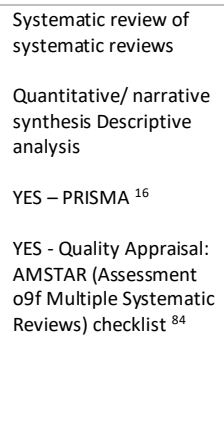 & Not reported & $\begin{array}{l}\mathrm{N}=6 \text { reviews } \\
\text { (96 original articles) } \\
\text { - Patients with palliative care } \\
\text { needs }\end{array}$ & Not reported & $\begin{array}{l}\text { Telemedicine: } \\
\text { - Telephone advice } \\
\text { lines } \\
\text { - Videophones } \\
\text { - Personal digital } \\
\text { assistants } \\
\text { - Pen tablets } \\
\text { - Computers }\end{array}$ & $\begin{array}{l}\text { - Clinical health-related } \\
\text { outcomes } \\
\text { - Col } \\
\text { - Caregiver perceptions of pain } \\
\text { management } \\
\text { : Symptom management } \\
\text { : Patient-physician relationship } \\
\text { - Pain management } \\
\text { - Education } \\
\text { : Advantages/ disadvantages } \\
\text { - Cfficacy of intervention } \\
\text { - Qust } \\
\text { - Patility of care } \\
\text { - compliacceptance and } \\
\text { - Feasibility }\end{array}$ & $\begin{array}{l}\text { - All included systematic reviews } \\
\text { considered telemedicine applications } \\
\text { as a feasible means to be used in } \\
\text { palliative care; however, the positive } \\
\text { findings are counterbalanced by } \\
\text { several critical issues mainly related to } \\
\text { the evidence from the primary studies } \\
\text { included in each single review. } \\
\text { - Results of this first attempt to appraise } \\
\text { the evidence in the field of } \\
\text { telemedicine applications in palliative } \\
\text { care highlighted that there is still } \\
\text { limited evidence related to this } \\
\text { approach. }\end{array}$ \\
\hline $\begin{array}{l}\text { Zheng et al. 201151 } \\
(2007-2012)\end{array}$ & $\begin{array}{l}\text { To evaluate } \\
\text { caregiver outcomes } \\
\text { related to palliative } \\
\text { telehealth } \\
\text { interventions. }\end{array}$ & $\begin{array}{l}\text { Systematic review } \\
\text { Descriptive analysis } \\
\text { YES - PRISMA }{ }^{16} \\
\text { YES - Quality Appraisal: } \\
\text { Cochrane } \\
\text { Collaboration's tool }{ }^{81}\end{array}$ & $\begin{array}{l}\text { Australia, USA, } \\
\text { Taiwan, Canada }\end{array}$ & $\begin{array}{l}\mathrm{N}=9 \\
\text { - Pooled analysis of two } \\
\text { randomised trials }(\mathrm{n}=1) \\
\text { - Randomised non-inferiority trial } \\
\text { (n } \mathrm{n} 2) \\
\text { - Prospective exploratory cohort } \\
\text { study }(\mathrm{n}=1) \\
\text { - Sequential mixed method two- } \\
\text { phase design ( } \mathrm{n}=1) \\
\text { - Two-group non-randomised pre- } \\
\text { test/post-test design }(\mathrm{n}=1) \\
\text { - Mixed-methods analysis of } \\
\text { - multiple data sources }(n=1) \\
\text { - pilot pre-/post intervention }\end{array}$ & $\begin{array}{l}\mathrm{N}=517 \\
\text { Same range: 8-217 } \\
\text { Palliative or end-of-life } \\
\text { care: } \\
\text { : HF } \\
\text { Cancer }\end{array}$ & $\begin{array}{l}\text { Telehealth: } \\
\text { - Telehealth } \\
\text { consultations } \\
\text { - Videophones } \\
\text { - RPM } \\
\text { - Telephone }\end{array}$ & $\begin{array}{l}\text { - Caregiver QOL } \\
\text { - Caregiver mood/anxiety } \\
\text { - Caregiver burden } \\
\text { - Family functioning } \\
\text { - Social support }\end{array}$ & $\begin{array}{l}\text { - All the studies measuring caregiver } \\
\text { QOL showed no significant difference } \\
\text { after telehealth interventions. } \\
\text { - The caregiver anxiety score decreased } \\
\text { after the intervention in two studies, } \\
\text { and one study reported significantly } \\
\text { reduced caregiver burden. } \\
\text { - Although feasibility of telehealth or } \\
\text { caregiver satisfaction with the } \\
\text { telehealth intervention was not the } \\
\text { focus of this review, most studies } \\
\text { reported such findings. }\end{array}$ \\
\hline
\end{tabular}




\begin{tabular}{|c|c|c|c|c|c|c|c|c|}
\hline & & & & $\begin{array}{ll} & \text { survey design }(\mathrm{n}=1) \\
\text { - } & \text { Mixed-method case study ( } \mathrm{n}=1) \\
\text { - } & \text { single-group feasibility study } \\
(\mathrm{n}=1)\end{array}$ & & & & \\
\hline $\begin{array}{l}\text { Allsop et al. } 2015^{29} \\
(1990-2012)\end{array}$ & $\begin{array}{l}\text { To review existing } \\
\text { ICT systems } \\
\text { intended to support } \\
\text { management of pain } \\
\text { in palliative care } \\
\text { patients with } \\
\text { cancer. }\end{array}$ & $\begin{array}{l}\text { Systematic review } \\
\text { Descriptive analysis } \\
\text { YES - PRISMA }{ }^{16} \\
\text { NO- Quality Appraisal }\end{array}$ & $\begin{array}{l}\text { USA, Sweden, UK, } \\
\text { Austria, Germany, } \\
\text { Japan, Norway }\end{array}$ & $\begin{array}{l}N=24 \\
\text { Waiting room (n=12) } \\
\text { Home }(n=8) \\
\text { Community }(n=4) \\
\text { - Randomised experiment }(n=4) \\
\text { - Non-randomised experiment } \\
\text { (n=1) } \\
\text { - Observational }(n=1) \\
\text { - Survey design }(n=2) \\
\text { System description }(n=2) \\
\text { - Expert opinion }(n=1) \\
\text { - Non-specified non-experimental } \\
\text { study design }(n=13)\end{array}$ & $\begin{array}{l}\text { Not reported } \\
\text { Palliative care patients } \\
\text { with: } \\
\text { - Cancer }\end{array}$ & $\begin{array}{l}\text { ICTs: } \\
\text { - Management tool } \\
\text { for remote patient } \\
\text { identification, } \\
\text { assessment and } \\
\text { monitoring of pain }\end{array}$ & - Pain assessment & $\begin{array}{l}\text { - Studies were identified at different } \\
\text { stages of development with no } \\
\text { systems having reached } \\
\text { implementation. } \\
\text { Most systems captured pain as part of } \\
\text { QOL measurement with wide } \\
\text { variation in approaches to pain } \\
\text { assessment. }\end{array}$ \\
\hline
\end{tabular}

ACP, advance care planning; AMSTAR, Assessing the Methodological Quality of Systematic Reviews; BP, blood pressure; CASP, Critical Appraisal Skills Programme COPD, chronic obstructive pulmonary disease; EOL, end of life; ESRD, end-stage renal disease; GP, general practitioner; HF, heart failure; HIV / AIDS, Human Immunodeficiency Virus / Acquired Immunodeficiency Syndrome; HP, health professionals; ICT, information and communication technology N, number; NA, not message service; TIDieR, The Template for Intervention Description and Replication 
Table 3. Assessing quality and risk of bias in included reviews using ROBIS phase 2 domains and phase 3.

\begin{tabular}{|c|c|c|c|c|c|c|}
\hline \multirow[t]{2}{*}{ Review } & \multicolumn{4}{|l|}{ Phase 2} & \multirow{2}{*}{$\begin{array}{l}\text { Phase } 3 \\
\text { Risk of } \\
\text { bias in } \\
\text { the } \\
\text { review }\end{array}$} & \multirow[t]{2}{*}{ Concerns } \\
\hline & $\begin{array}{l}\text { Study } \\
\text { eligibility } \\
\text { criteria }\end{array}$ & $\begin{array}{l}\text { Identification } \\
\text { and selection } \\
\text { of studies }\end{array}$ & $\begin{array}{l}\text { Data collection } \\
\text { and study } \\
\text { appraisal }\end{array}$ & $\begin{array}{l}\text { Synthesis and } \\
\text { findings }\end{array}$ & & \\
\hline $\begin{array}{l}\text { Johnston et } \\
\text { al. } 2020^{27}\end{array}$ & $\begin{array}{l}1.1-Y \\
1.2-Y \\
1.3-Y \\
1.4-Y \\
1.5-Y \\
-;\end{array}$ & $\begin{array}{l}2.1-Y \\
2.2-Y \\
2.3-Y \\
2.4-Y \\
2.5-Y \\
-;\end{array}$ & $\begin{array}{l}3.1-Y \\
3.2-Y \\
3.3-Y \\
3.4-Y \\
3.5-Y \\
-;\end{array}$ & $\begin{array}{l}4.1-Y \\
4.2-Y \\
4.3-Y \\
4.4-Y \\
4.5-N \\
4.6-Y \\
: ;\end{array}$ & (;) & $\begin{array}{l}\text { No studies were } \\
\text { included in the } \\
\text { synthesis due to } \\
\text { low quality of } \\
\text { studies. }\end{array}$ \\
\hline $\begin{array}{l}\text { Widberg et } \\
\text { al. } 2020^{26}\end{array}$ & $\begin{array}{l}1.1-Y \\
1.2-Y \\
1.3-Y \\
1.4-Y \\
1.5-Y \\
+;\end{array}$ & $\begin{array}{l}2.1-Y \\
2.2-N \\
2.3-P Y \\
2.4-Y \\
2.5-Y \\
\end{array}$ & $\begin{array}{l}3.1-P Y \\
3.2-Y \\
3.3-Y \\
3.4-Y \\
3.5-Y \\
(:)\end{array}$ & $\begin{array}{l}4.1-Y \\
4.2-Y \\
4.3-Y \\
4.4-Y \\
4.5-N \\
4.6-N \\
?\end{array}$ & (;) & $\begin{array}{l}\text { Biases in included } \\
\text { studies minimally } \\
\text { addressed in the } \\
\text { synthesis. }\end{array}$ \\
\hline $\begin{array}{l}\text { Portz et al. } \\
202028\end{array}$ & $\begin{array}{l}1.1-Y \\
1.2-Y \\
1.3-Y \\
1.4-Y \\
1.5-Y \\
(-)\end{array}$ & $\begin{array}{l}2.1-Y \\
2.2-Y \\
2.3-Y \\
2.4-Y \\
2.5-Y \\
\end{array}$ & $\begin{array}{l}3.1-Y \\
3.2-Y \\
3.3-Y \\
3.4-N \\
3.5-N \\
+:\end{array}$ & $\begin{array}{l}4.1-Y \\
4.2-Y \\
4.3-Y \\
4.4-N \\
4.5-P N \\
4.6-N \\
: \theta\end{array}$ & (:) & $\begin{array}{l}\text { No critical } \\
\text { appraisal or risk of } \\
\text { bias assessed. }\end{array}$ \\
\hline $\begin{array}{l}\text { Sutherland } \\
\text { et al. } 2020 \\
52\end{array}$ & $\begin{array}{l}1.1-Y \\
1.2-Y \\
1.3-Y \\
1.4-Y \\
1.5-Y \\
(;)\end{array}$ & $\begin{array}{l}2.1-P Y \\
2.2-N \\
2.3-P Y \\
2.4-Y \\
2.5-N \\
?\end{array}$ & $\begin{array}{l}3.1-\mathrm{NI} \\
3.2-\mathrm{PN} \\
3.3-\mathrm{Y} \\
3.4-\mathrm{N} \\
3.5-\mathrm{N} \\
?\end{array}$ & $\begin{array}{l}4.1-P Y \\
4.2-Y \\
4.3-Y \\
4.4-N \\
4.5-P Y \\
4.6-N \\
?\end{array}$ & $\theta$ & $\begin{array}{l}\text { Only used two } \\
\text { databases, and } \\
\text { include } 2 \\
\text { systematic reviews } \\
\text { and } 1 \text { guideline - } \\
\text { unusual inclusion. }\end{array}$ \\
\hline $\begin{array}{l}\text { Steindal et } \\
\text { al. } 2020^{35}\end{array}$ & $\begin{array}{l}1.1-Y \\
1.2-Y \\
1.3-Y \\
1.4-Y \\
1.5-Y \\
-;\end{array}$ & $\begin{array}{l}2.1-Y \\
2.2-Y \\
2.3-Y \\
2.4-Y \\
2.5-Y \\
:-)\end{array}$ & $\begin{array}{l}3.1-Y \\
3.2-Y \\
3.3-Y \\
3.4-Y \\
3.5-Y \\
(-)\end{array}$ & $\begin{array}{l}4.1-Y \\
4.2-Y \\
4.3-Y \\
4.4-Y \\
4.5-Y \\
4.6-Y \\
:-)\end{array}$ & (:) & \\
\hline $\begin{array}{l}\text { Holmen et } \\
\text { al. } 202048\end{array}$ & $\begin{array}{l}1.1-Y \\
1.2-Y \\
1.3-Y \\
1.4-Y \\
1.5-Y \\
(-)\end{array}$ & $\begin{array}{l}2.1-Y \\
2.2-\mathrm{NI} \\
2.3-\mathrm{Y} \\
2.4-\mathrm{Y} \\
2.5-\mathrm{Y} \\
-;\end{array}$ & $\begin{array}{l}3.1-Y \\
3.2-Y \\
3.3-Y \\
3.4-Y \\
3.5-Y \\
\end{array}$ & $\begin{array}{l}4.1-Y \\
4.2-Y \\
4.3-Y \\
4.4-Y \\
4.5-P Y \\
4.6-Y \\
:-)\end{array}$ & (:) & \\
\hline $\begin{array}{l}\text { Jess et al. } \\
2019^{49}\end{array}$ & $\begin{array}{l}1.1-Y \\
1.2-Y \\
1.3-Y \\
1.4-Y \\
1.5-Y \\
(-)\end{array}$ & $\begin{array}{l}2.1-Y \\
2.2-Y \\
2.3-Y \\
2.4-Y \\
2.5-Y \\
\end{array}$ & $\begin{array}{l}3.1-Y \\
3.2-Y \\
3.3-Y \\
3.4-Y \\
3.5-Y \\
\end{array}$ & $\begin{array}{l}4.1-Y \\
4.2-Y \\
4.3-Y \\
4.4-Y \\
4.5-P Y \\
4.6-Y \\
: ;\end{array}$ & (;) & \\
\hline $\begin{array}{l}\text { Hancock et } \\
\text { al. } 2019^{30}\end{array}$ & $\begin{array}{l}1.1-Y \\
1.2-Y \\
1.3-Y \\
1.4-Y \\
1.5-Y\end{array}$ & $\begin{array}{l}2.1-Y \\
2.2-Y \\
2.3-Y \\
2.4-Y \\
2.5-Y\end{array}$ & $\begin{array}{l}3.1-Y \\
3.2-Y \\
3.3-Y \\
3.4-P Y \\
3.5-P Y\end{array}$ & $\begin{array}{l}4.1-Y \\
4.2-Y \\
4.3-Y \\
4.4-Y \\
4.5-P Y \\
4.6-Y\end{array}$ & (:) & $\begin{array}{l}\text { Although criteria } \\
\text { used for review of } \\
\text { study quality were } \\
\text { adapted from } \\
\text { existing literature, } \\
\text { they were }\end{array}$ \\
\hline
\end{tabular}




\begin{tabular}{|c|c|c|c|c|c|c|}
\hline & (:) & (:) & ;); & ;:) & & $\begin{array}{l}\text { developed by the } \\
\text { authors and } \\
\text { assessed by the } \\
\text { authors, creating } \\
\text { scope for bias. }\end{array}$ \\
\hline $\begin{array}{l}\text { Allsop et al. } \\
2018^{32}\end{array}$ & $\begin{array}{l}1.1-Y \\
1.2-Y \\
1.3-Y \\
1.4-Y \\
1.5-Y \\
\end{array}$ & $\begin{array}{l}2.1-Y \\
2.2-Y \\
2.3-P Y \\
2.4-Y \\
2.5-Y \\
\end{array}$ & $\begin{array}{l}3.1-Y \\
3.2-Y \\
3.3-Y \\
3.4-N \\
3.5-N \\
?\end{array}$ & $\begin{array}{l}4.1-P Y \\
4.2-Y \\
4.3-Y \\
4.4-Y \\
4.5-P Y \\
4.6-N \\
?\end{array}$ & $?$ & $\begin{array}{l}\text { No quality } \\
\text { assessment was } \\
\text { used to rate risk of } \\
\text { bias in included } \\
\text { studies. }\end{array}$ \\
\hline $\begin{array}{l}\text { Lunney et } \\
\text { al. } 2018^{31}\end{array}$ & $\begin{array}{l}1.1-Y \\
1.2-Y \\
1.3-Y \\
1.4-Y \\
1.5-Y \\
\end{array}$ & $\begin{array}{l}2.1-Y \\
2.2-Y \\
2.3-Y \\
2.4-Y \\
2.5-Y \\
\end{array}$ & $\begin{array}{l}3.1-Y \\
3.2-Y \\
3.3-Y \\
3.4-N \\
3.5-N \\
?\end{array}$ & $\begin{array}{l}4.1-Y \\
4.2-Y \\
4.3-Y \\
4.4-Y \\
4.5-P Y \\
4.6-N \\
?\end{array}$ & $?$ & $\begin{array}{l}\text { No quality } \\
\text { assessment was } \\
\text { used to rate risk of } \\
\text { bias in included } \\
\text { studies. }\end{array}$ \\
\hline $\begin{array}{l}\text { Head et al. } \\
2017^{34}\end{array}$ & $\begin{array}{l}1.1-Y \\
1.2-Y \\
1.3-Y \\
1.4-Y \\
1.5-Y \\
\end{array}$ & $\begin{array}{l}2.1-\mathrm{Y} \\
2.2-\mathrm{N} \\
2.3-\mathrm{NI} \\
2.4-\mathrm{Y} \\
2.5-\mathrm{PY} \\
?\end{array}$ & $\begin{array}{l}3.1-\mathrm{NI} \\
3.2-\mathrm{Y} \\
3.3-\mathrm{Y} \\
3.4-\mathrm{Y} \\
3.5-\mathrm{NI} \\
?\end{array}$ & $\begin{array}{l}4.1-Y \\
4.2-Y \\
4.3-Y \\
4.4-Y \\
4.5-P Y \\
4.6-Y \\
:-)\end{array}$ & $?$ & $\begin{array}{l}\text { Very basic search } \\
\text { terms - no search } \\
\text { strategy provided. } \\
\text { Methods section is } \\
\text { limited. Does not } \\
\text { explain how the } \\
\text { quality appraisal } \\
\text { tool was used and } \\
\text { how many authors } \\
\text { performed it. }\end{array}$ \\
\hline $\begin{array}{l}\text { Pinto et al. } \\
2017^{53}\end{array}$ & $\begin{array}{l}1.1-Y \\
1.2-Y \\
1.3-Y \\
1.4-Y \\
1.5-Y \\
\end{array}$ & $\begin{array}{l}2.1-\mathrm{PN} \\
2.2-\mathrm{Y} \\
2.3-\mathrm{PN} \\
2.4-\mathrm{Y} \\
2.5-\mathrm{NI} \\
?\end{array}$ & $\begin{array}{l}3.1-P Y \\
3.2-Y \\
3.3-Y \\
3.4-N \\
3.5-N \\
?\end{array}$ & $\begin{array}{l}4.1-Y \\
4.2-Y \\
4.3-Y \\
4.4-Y \\
4.5-P Y \\
4.6-N \\
:-)\end{array}$ & $?$ & $\begin{array}{l}\text { Surprising that } \\
\text { they didn't use the } \\
\text { term App, } \\
\text { smartphone, in } \\
\text { their search } \\
\text { strategy. } \\
\text { No critical } \\
\text { appraisal or risk of } \\
\text { bias assessed. }\end{array}$ \\
\hline $\begin{array}{l}\text { Ostherr et } \\
\text { al. } 2016^{50}\end{array}$ & $\begin{array}{l}1.1-Y \\
1.2-Y \\
1.3-Y \\
1.4-Y \\
1.5-Y \\
\end{array}$ & $\begin{array}{l}2.1-Y \\
2.2-N \\
2.3-Y \\
2.4-Y \\
2.5-Y \\
-;\end{array}$ & $\begin{array}{l}3.1-Y \\
3.2-Y \\
3.3-Y \\
3.4-Y \\
3.5-\mathrm{NI} \\
\end{array}$ & $\begin{array}{l}4.1-Y \\
4.2-Y \\
4.3-Y \\
4.4-Y \\
4.5-P Y \\
4.6-Y \\
:-)\end{array}$ & (;) & \\
\hline $\begin{array}{l}\text { Rogante et } \\
\text { al. } 2016^{33}\end{array}$ & $\begin{array}{l}1.1-Y \\
1.2-Y \\
1.3-Y \\
1.4-Y \\
1.5-Y \\
\end{array}$ & $\begin{array}{l}2.1-Y \\
2.2-N \\
2.3-P Y \\
2.4-Y \\
2.5-P Y \\
\end{array}$ & $\begin{array}{l}3.1-P Y \\
3.2-Y \\
3.3-Y \\
3.4-Y \\
3.5-Y \\
\end{array}$ & $\begin{array}{l}4.1-Y \\
4.2-Y \\
4.3-Y \\
4.4-Y \\
4.5-P Y \\
4.6-Y \\
: ;\end{array}$ & (:) & \\
\hline $\begin{array}{l}\text { Zheng et al. } \\
2016^{51}\end{array}$ & $\begin{array}{l}1.1-Y \\
1.2-Y \\
1.3-Y \\
1.4-Y \\
1.5-Y \\
\end{array}$ & $\begin{array}{l}2.1-\mathrm{Y} \\
2.2-\mathrm{N} \\
2.3-\mathrm{PY} \\
2.4-\mathrm{Y} \\
2.5-\mathrm{NI} \\
?\end{array}$ & $\begin{array}{l}3.1-Y \\
3.2-Y \\
3.3-Y \\
3.4-Y \\
3.5-Y \\
\end{array}$ & $\begin{array}{l}4.1-Y \\
4.2-Y \\
4.3-Y \\
4.4-Y \\
4.5-P Y \\
4.6-Y \\
:-)\end{array}$ & ;) & $\begin{array}{l}\text { Search terms and } \\
\text { structure of search } \\
\text { strategy what short } \\
\text { and broad. }\end{array}$ \\
\hline $\begin{array}{l}\text { Allsop et al. } \\
201529\end{array}$ & $\begin{array}{l}1.1-Y \\
1.2-Y \\
1.3-Y\end{array}$ & $\begin{array}{l}2.1-Y \\
2.2-N \\
2.3-Y\end{array}$ & $\begin{array}{l}3.1-Y \\
3.2-Y \\
3.3-Y\end{array}$ & $\begin{array}{l}4.1-Y \\
4.2-Y \\
4.3-Y\end{array}$ & (;) & $\begin{array}{l}\text { No critical } \\
\text { appraisal or risk of } \\
\text { bias assessed. }\end{array}$ \\
\hline
\end{tabular}




\begin{tabular}{|c|c|c|c|}
\hline $\begin{array}{l}1.4-Y \\
1.5-Y \\
(-)\end{array}$ & $\begin{array}{l}2.4-Y \\
2.5-Y \\
\\
\text { :) }\end{array}$ & $\begin{array}{l}3.4-\mathrm{N} \\
3.5-\mathrm{N} \\
?\end{array}$ & $\begin{array}{l}4.4-\mathrm{Y} \\
4.5-\mathrm{PN} \\
4.6-\mathrm{N} \\
\dot{-(;}\end{array}$ \\
\hline
\end{tabular}

Summary of the ROBIS Assessment. Risk of bias is judged as "low," "high," or "unclear."

(:) = low risk; $:$ = high risk; ? = unclear risk 
Table 4. Barriers and facilitators to virtual palliative care strategies

\begin{tabular}{|c|c|c|c|c|}
\hline & Barriers & & Facilitators & \\
\hline \multirow{9}{*}{$\begin{array}{l}\text { Systems } \\
\text { level }\end{array}$} & Lack of broadband coverage/ internet access & 30,53 & Ease of use / user-friendliness/ simplicity & $35,48,49$ \\
\hline & Lack of adequate resources & 49 & External support managing coordination of virtual consultations & 48,49 \\
\hline & Quality impacting video and audio resolution & $\begin{array}{l}48,49 \\
52\end{array}$ & $\begin{array}{l}\text { A need to improve infrastructure to support telehealth/administrative } \\
\text { support in setting up remote consultations }\end{array}$ & 30,52 \\
\hline & Rigid firewalls & 48 & Better integration between hospital and community services & 53 \\
\hline & Security concerns/issues & 53 & $\begin{array}{l}\text { Using a standard operating procedure or clinical protocol stipulating } \\
\text { when telehealth interventions can/cannot be used }\end{array}$ & 52 \\
\hline & Slow internet speed & 48 & $\begin{array}{l}\text { Policies to minimise the risk of reduced equity of access in } \\
\text { disadvantaged populations }\end{array}$ & 52 \\
\hline & Lack of leadership and encouragement from management & 49 & & \\
\hline & The system is expensive/ internet access expensive & 48 & & \\
\hline & Lack of funding & 30 & & \\
\hline \multirow[t]{4}{*}{$\begin{array}{l}\text { Clinician } \\
\text { level }\end{array}$} & $\begin{array}{l}\text { Clinician perception that intervention inappropriate for population due to age, } \\
\text { burden of illness and rapidity of deterioration ("Gate-keeping") }\end{array}$ & $\begin{array}{l}30,34, \\
52\end{array}$ & $\begin{array}{l}\text { Positive attitude to video enabled consultations, viewing it as a way to } \\
\text { enable digital connectedness. Clinicians viewed it as a way to observe } \\
\text { body language and nonverbal cues. }\end{array}$ & $\begin{array}{l}35,48 \\
49,52\end{array}$ \\
\hline & Negative perception of not being able to physically comfort patient or caregiver & 48,52 & $\begin{array}{l}\text { Clinician training and skill in video consultation technology and how to } \\
\text { interact and communicate by video. }\end{array}$ & 49,52 \\
\hline & $\begin{array}{l}\text { Health professional preference for face-to-face } \\
\text { HP perception - time consuming compared to face-to-face/increases workload }\end{array}$ & $\begin{array}{l}48,49 \\
52,53\end{array}$ & & \\
\hline & $\begin{array}{l}\text { Lack of consensus among HPs on criteria for appropriate referral of patients for } \\
\text { virtual/video consultations }\end{array}$ & 49 & & \\
\hline \multirow{3}{*}{$\begin{array}{l}\text { Patient / } \\
\text { carer } \\
\text { level }\end{array}$} & Poor health condition, physical limitations & 35 & Patient willingness to use telehealth systems & 35 \\
\hline & Possible intrusion and reminder of being sick & 48 & Positive experiences and attitudes to telehealth interventions & 52 \\
\hline & Perceived potential for patient difficulty managing the technology & 30 & Portability of devices & 49 \\
\hline
\end{tabular}


Preference for face-to-face

Not comfortable being on video

53

Unfamiliarity with telehealth equipment / Low literacy or few digital literacy skills

Patients requiring assistance from a third person/family member to use the system.

Challenges with design of equipment e.g. small font size on smartphones, small size of videophones, lack of equipment portability

People with limited control over or access to mobile devices e.g. people speaking minority languages, migrant populations in new settings

Limited access to the required equipment

35,52

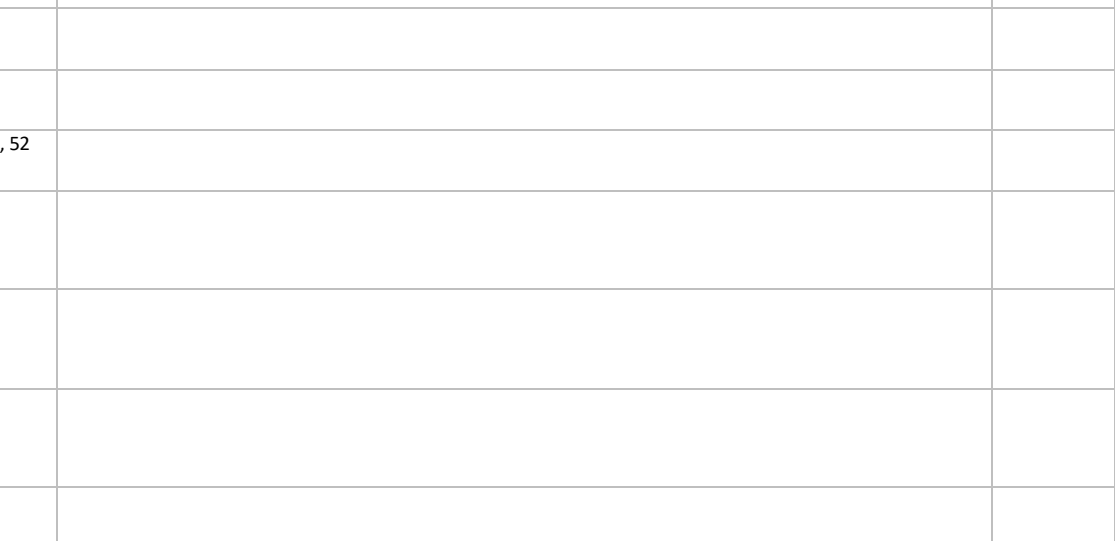

